\title{
Subsolidus Phase Relations of the CoOx-CuO-SrO System
}

\section{Grivel, Jean-Claude}

\section{Published in:}

Journal of Phase Equilibria and Diffusion

Link to article, DOI:

$10.1007 / \mathrm{s} 11669-017-0581-4$

Publication date:

2017

Document Version

Peer reviewed version

Link back to DTU Orbit

Citation (APA):

Grivel, J-C. (2017). Subsolidus Phase Relations of the $\mathrm{CoO}$-CuO-SrO System . Journal of Phase Equilibria and Diffusion, 38(5), 646-655. https://doi.org/10.1007/s1166-017-0581-4

\section{General rights}

Copyright and moral rights for the publications made accessible in the public portal are retained by the authors and/or other copyright owners and it is a condition of accessing publications that users recognise and abide by the legal requirements associated with these rights.

- Users may download and print one copy of any publication from the public portal for the purpose of private study or research.

- You may not further distribute the material or use it for any profit-making activity or commercial gain

- You may freely distribute the URL identifying the publication in the public portal

If you believe that this document breaches copyright please contact us providing details, and we will remove access to the work immediately and investigate your claim 


\title{
Subsolidus phase relations of the $\mathrm{CoO}_{\mathrm{x}}-\mathrm{CuO}-\mathrm{SrO}$ system
}

\author{
J.-C. Grivel* \\ Department of Energy Conversion and Storage, Technical University of Denmark, \\ Frederiksborgvej 399, DK-4000 Roskilde, Denmark
}

\begin{abstract}
Abtract
The subsolidus phase relations of the $\mathrm{CoO}_{\mathrm{x}}-\mathrm{CuO}-\mathrm{SrO}$ system were investigated in air. The samples were equilibrated at $900^{\circ} \mathrm{C}$. The pseudo-ternary section contains three stoichiometric binary oxide phases $\left(\mathrm{Sr}_{2} \mathrm{CuO}_{3}, \mathrm{SrCuO}_{2}\right.$ and $\left.\mathrm{Sr}_{14} \mathrm{Cu}_{24} \mathrm{O}_{41-\delta}\right)$ and a binary oxide solid solution: $\operatorname{Sr}_{6+\mathrm{x}} \mathrm{Co}_{5} \mathrm{O}_{15+\delta}(0 \leq \mathrm{x} \leq 0.36)$. Two binary phases extend into the ternary system forming solid solutions, i.e. $\operatorname{Sr}_{14} \mathrm{Cu}_{24-\mathrm{x}} \mathrm{Co}_{\mathrm{x}} \mathrm{O}_{41-\delta}(0 \leq \mathrm{x} \leq 5)$ and $\mathrm{Sr}_{6+\mathrm{x}} \mathrm{Co}_{5-\mathrm{y}} \mathrm{Cu}_{\mathrm{y}} \mathrm{O}_{15+\delta}(0 \leq \mathrm{x} \leq 0.36,0 \leq \mathrm{y} \leq 1.0)$. $\mathrm{The} \mathrm{Sr}_{6+\mathrm{x}} \mathrm{Co}_{5} \mathrm{O}_{15+\delta}$ solid solution was found to undergo a phase separation into a mixture of $\mathrm{Sr}_{6} \mathrm{Co}_{5} \mathrm{O}_{15-\delta}$ and $\mathrm{Sr}_{14} \mathrm{Co}_{11} \mathrm{O}_{33}$ upon annealing at $600^{\circ} \mathrm{C}$. This transformation is reversible.
\end{abstract}

Keywords: Experimental phase equilibria, isothermal section, oxide systems, pseudoternary

*Corresponding author. Tel. +45 46774739; fax: +45 46775758.

E-mail address: jean@dtu.dk 


\section{Introduction}

The sensational discovery of high-temperature superconductivity in $\mathrm{La}_{2-\mathrm{x}} \mathrm{Ba}_{\mathrm{x}} \mathrm{CuO}_{4-\delta}$ in 1986 [1], induced tremendous research activity to find new cuprate compounds with higher transition temperatures. Among other strategies, the phase equilibria of many pseudo-ternary phase diagrams including $\mathrm{CuO}$ and an alkaline earth oxide (mostly $\mathrm{BaO}, \mathrm{SrO}$ or $\mathrm{CaO}$ ) have been screened. However, while combinations of those oxides with rare-earth oxides have been systematically studied ([2] and references therein), combinations consisting of $\mathrm{CuO}, \mathrm{SrO}$ and oxides of transition metals (TM) are still poorly investigated. The published phase diagrams of $\mathrm{CuO}-$ $\mathrm{SrO}-\mathrm{TM}$-oxide systems are limited to $\mathrm{TM}=\mathrm{V}$ [3], $\mathrm{Nb}$ [4,5], $\mathrm{Fe}[6], \mathrm{Ti}[7,8], \mathrm{Zr}$ and Hf [8], Ta [9] and W [10]. Cobalt, being magnetic, is not in principle expected to be favourable for the appearance of superconductivity. However, mixing elements such as $\mathrm{Cu}$ and $\mathrm{Co}$ in ternary oxide compounds or solid solutions could result in interesting effects. It was therefore important to study the possibility of reciprocal doping in the binary oxides of the $\mathrm{Co}-\mathrm{Sr}-\mathrm{O}$ and $\mathrm{Cu}-\mathrm{Sr}-\mathrm{O}$ systems and to assess the occurrence of ternary oxide compounds in the $\mathrm{CoO}_{\mathrm{x}}-\mathrm{CuO}-\mathrm{SrO}$ system. The equilibration conditions (i.e. $900^{\circ} \mathrm{C}$ in air) were selected, because they correspond to conditions similar to those employed for preparing compounds that exhibit high superconducting transition temperatures, i.e. reaction at $865^{\circ} \mathrm{C}-910^{\circ} \mathrm{C}$ in air $[11,12]$.

\section{Previous work}

(1) $\mathrm{CuO}-\mathrm{SrO}$

This pseudo-binary system has been studied in detail, in particular in relation to the advent of high-temperature superconductors [13-18]. In air, three intermediate phases are stable: $\mathrm{Sr}_{2} \mathrm{CuO}_{3}, \mathrm{SrCuO}_{2}$ and $\mathrm{Sr}_{14} \mathrm{Cu}_{24} \mathrm{O}_{41}$, the latter being sometimes referred to as $\mathrm{Sr}_{3} \mathrm{Cu}_{5} \mathrm{O}_{8}$. All three are stable at $900^{\circ} \mathrm{C}$. An additional binary oxide phase with $\mathrm{SrCu}_{2} \mathrm{O}_{2}$ composition is stable under low oxygen partial pressure conditions only ( $\mathrm{p}_{\mathrm{O} 2}$ 
$<0.06$ at $\left.900^{\circ} \mathrm{C}\right)[17,18]$. The $\mathrm{SrCu}_{2} \mathrm{O}_{3}$ and $\mathrm{Sr}_{2} \mathrm{Cu}_{3} \mathrm{O}_{5}$ phases were synthesised under high pressure $(1.7 \mathrm{GPa}-8 \mathrm{GPa})[19]$.

(2) $\mathrm{CoO}_{x}-\mathrm{CuO}$

Two early experimental studies on this system have been published [20,21]. In both, the samples were equilibrated in air. However, Landolt and Muan [21] only reported the phase equilibria between $1000^{\circ} \mathrm{C}$ and $1120^{\circ} \mathrm{C}$. In contrast, the work by Driessens et al [20] covers the $600^{\circ} \mathrm{C}$ to $1150^{\circ} \mathrm{C}$ range. More recently, Zabdyr and Fabrichnaya [22] reassessed the system between $727^{\circ} \mathrm{C}$ and $1127^{\circ} \mathrm{C}$ by means of calculations based on previously published data as well as a set of new EMF measurements performed on 8 compositions and further included a description of the liquidus as part of a study of the $\mathrm{Co}-\mathrm{Cu}-\mathrm{O}-\mathrm{Si}$ system [23]. At $900^{\circ} \mathrm{C}$, these authors found that $\mathrm{Co}$ can dissolve into the monoclinic $\mathrm{CuO}$ tenorite phase up to a little less than 5 at.\%, i.e. $\mathrm{Cu}_{1-\mathrm{x}} \mathrm{Co}_{\mathrm{x}} \mathrm{O}_{1+\delta}(\mathrm{x} \approx 0.05)$ [22]. Co substitution in $\mathrm{CuO}$ was also reported in [21], although the solubility limit was closer to $\mathrm{x}=0.03$ at $1000^{\circ} \mathrm{C}$ and appeared to decrease with temperature. In contrast, Driessens et al. [20] found no measurable Co solubility in $\mathrm{CuO}$.

For higher Co contents, references [22] and [20] agree on the existence of a twophase region with equilibrium between $\mathrm{CuO}$ and a Co-rich cubic rock-salt phase. The maximum $\mathrm{Cu}$ solubility in this $\mathrm{Co}_{1-\mathrm{x}} \mathrm{Cu}_{\mathrm{x}} \mathrm{O}_{1-\delta}$ rock-salt solid-solution at $900^{\circ} \mathrm{C}$ is $\mathrm{x} \approx$ 0.33 [20] or $\mathrm{x} \approx 0.38$ [22]. Whereas the composition range of this phase at $900^{\circ} \mathrm{C}$ extends all the way to pure $\mathrm{CoO}$ according to Zabdyr and Fabrichnaya [22], Driessens et al. [20] report a lower value of $\mathrm{x} \approx 0.17$ at $900^{\circ} \mathrm{C}$ in $\mathrm{Co}_{1-\mathrm{x}} \mathrm{Cu}_{\mathrm{x}} \mathrm{O}_{1+\delta}$.

According to Driessens et al. [20], for lower $\mathrm{Cu}$ content, the cubic rock-salt phase co-exists with the cubic spinel $\mathrm{Co}_{3} \mathrm{O}_{4}$ phase, which itself admits $\mathrm{Cu}$ substitution up to nearly 10 at. $\%$ for $\mathrm{Co}$ at $865^{\circ} \mathrm{C}$. However, at $900^{\circ} \mathrm{C}$, the solubility limit is reduced to 
about 1 at.\%. Finally, the transition between $\mathrm{Co}_{3} \mathrm{O}_{4}$ and $\mathrm{CoO}$ for the pure cobaltoxygen system is given as $920^{\circ} \mathrm{C}$ in [20] versus $877^{\circ} \mathrm{C}$ in [22].

(3) $\mathrm{CoO}_{x}-\mathrm{SrO}$

The phase equilibria of the $\mathrm{SrO}-\mathrm{CoO}_{x}$ system in air have recently been reported by Jankovský et al. [24]. Earlier, several distinct binary oxide compounds had already been described, all being members of a general family with general formula $\mathrm{Sr}_{n+2} \mathrm{Co}_{n+1} \mathrm{O}_{3 n+3}(\mathrm{n}=1,2,3,4, \ldots)$. The Co-richest known phase is the $\mathrm{n}=\infty$ member: $\mathrm{SrCoO}_{3-\mathrm{x}}$, also described as $\mathrm{Sr}_{2} \mathrm{Co}_{2} \mathrm{O}_{5}$ [24]. This phase adopts the brownmillerite structure $[25,26]$ and was reported to undergo a structural transformation at lower temperatures [25] More recently, Harrison et al. [27] first demonstrated that the $\mathrm{Sr}_{2} \mathrm{Co}_{2} \mathrm{O}_{5}$ phase is in fact unstable in air below $900^{\circ} \mathrm{C}$ and decomposes into a mixture of $\mathrm{Sr}_{6} \mathrm{Co}_{5} \mathrm{O}_{15}$ and $\mathrm{Co}_{3} \mathrm{O}_{4}$ when annealed at $875^{\circ} \mathrm{C}$. This fact is confirmed in the detailed study of Jankovský et al. [24], who found that $\mathrm{Sr}_{2} \mathrm{Co}_{2} \mathrm{O}_{5}$ is only stable between $903^{\circ} \mathrm{C}$ and $1269^{\circ} \mathrm{C}$.

The $\mathrm{n}=1$ member of the $\mathrm{Sr}_{\mathrm{n}+2} \mathrm{Co}_{\mathrm{n}+1} \mathrm{O}_{3 \mathrm{n}+3}$ series, i.e. $\mathrm{Sr}_{3} \mathrm{Co}_{2} \mathrm{O}_{6}$ (orthorhombic, space group $\mathrm{Immm}$ ) is also a high temperature phase stable between $984^{\circ} \mathrm{C}$ and $1335^{\circ} \mathrm{C}$ [24]. According to Takami et al. [28], the $\mathrm{n}=2$ member, i.e. $\mathrm{Sr}_{4} \mathrm{Co}_{3} \mathrm{O}_{9}$ (trigonal, space group $\mathrm{P} 321$ ), can be synthesized by reaction of $\mathrm{Co}_{3} \mathrm{O}_{4}$ and $\mathrm{SrCO}_{3}$ at $800^{\circ} \mathrm{C}-$ $940^{\circ} \mathrm{C}$ in air. This phase is not present in the $\mathrm{SrO}-\mathrm{CoO}_{\mathrm{x}}$ phase diagram [24].

On the other hand, the $\mathrm{n}=3$ and $\mathrm{n}=4$ members $\left(\mathrm{Sr}_{5} \mathrm{Co}_{4} \mathrm{O}_{12}\right.$ and $\left.\mathrm{Sr}_{6} \mathrm{Co}_{5} \mathrm{O}_{15}\right)$, crystallising in the space groups $\mathrm{P} 3 \mathrm{c} 1$ and $\mathrm{R} 32$ respectively, have been reported as being stable at room temperature $[27,29]$. While $\mathrm{Sr}_{5} \mathrm{Co}_{4} \mathrm{O}_{12}$ is not present in the $\mathrm{Sr}$ Co-O diagram of Jankovský et al. [24], $\mathrm{Sr}_{6} \mathrm{Co}_{5} \mathrm{O}_{15}$ is reported to be stable up to $914^{\circ} \mathrm{C}$, whereas another phase described as $\mathrm{Sr}_{14} \mathrm{Co}_{11} \mathrm{O}_{33}$ is stable up to $1035^{\circ} \mathrm{C}$. The latter was first mentioned by Boulahya et al. [30], who rather describe the Sr-Co-O 
phases as members of a $\left(\mathrm{A}_{3} \mathrm{Co}_{2} \mathrm{O}_{6}\right)_{\alpha}\left(\mathrm{A}_{3} \mathrm{Co}_{3} \mathrm{O}_{9}\right)_{\beta}$ family, in which they also identified a compound with $\mathrm{Sr}_{21} \mathrm{Co}_{17} \mathrm{O}_{51}$ composition.

(4) $\mathrm{CoO}_{x}-\mathrm{CuO}-\mathrm{SrO}$

No study of this system appears to have been published so far. It is nevertheless known that 20 at. $\% \mathrm{Cu}$ in the $\mathrm{Sr}_{14} \mathrm{Cu}_{24} \mathrm{O}_{41-\delta}$ phase can be replaced by Co [31], while $\mathrm{SrCoO}_{2}$ may also allow some limited Co substitution on $\mathrm{Cu}$ sites [32]. In contrast, there seems to be no report on $\mathrm{Cu}$ substitution in the binary Sr-Co oxide phases.

\section{Experimental details}

70 different nominal compositions were studied. $\mathrm{Co}_{3} \mathrm{O}_{4}$ (Alfa Aesar 99.7\%), $\mathrm{SrCO}_{3}$ (Aldrich 99.9\%) and $\mathrm{CuO}$ (Aldrich 99.99\%) were used as starting reagents. The powders were thoroughly mixed in an agate mortar and calcined at $900 \pm 5^{\circ} \mathrm{C}$ for $25 \mathrm{~h}$. After grinding, $1 \mathrm{~g}$ pellets with $12 \mathrm{~mm}$ diameter were pressed under a pressure of 1.8 kbar and sintered at least twice at $900 \pm 5^{\circ} \mathrm{C}$ for $60 \mathrm{~h}$ with intermediate grinding and repressing. The samples were air-quenched at the end of each sintering step. All manipulations and heat treatments were performed in air.

The phase content of the pellets was checked after each sintering step by X-ray diffraction in a STOE diffractometer using $\mathrm{CuK}_{\alpha}$ radiation. In some cases, additional heat treatments were performed in order to reach equilibrium, which was considered as achieved when no differences were detectable in the XRD patterns after two consecutive heat treatments. Si powder was added as an internal standard for lattice parameter determination.

Electrical resistivity measurements were performed with a current of $1 \mathrm{~mA}$ by the 4 contacts method on samples cut into parallelepiped shapes with $1.5 \times 1.5 \mathrm{~mm}^{2}$ crosssection and $8 \mathrm{~mm}$ length. Gold wires were attached with silver paste cured at $200^{\circ} \mathrm{C}$.

\section{Results and discussion}

(1) $\mathrm{CuO}-\mathrm{SrO}$ 
In this system, the three binary oxide phases $\mathrm{Sr}_{2} \mathrm{CuO}_{3}, \mathrm{SrCuO}_{2}$ and $\mathrm{Sr}_{14} \mathrm{Cu}_{24} \mathrm{O}_{41-\delta}$ were formed in full agreement with previous studies of the binary $\mathrm{SrO}-\mathrm{CuO}$ phase diagram [13-18] as well as pseudo-ternary systems containing $\mathrm{SrO}$ and $\mathrm{CuO}$ for which phase equilibria have been established in air at $900^{\circ} \mathrm{C}-930^{\circ} \mathrm{C}[7,9,33-38]$.

(2) $\mathrm{CoO}_{x}-\mathrm{CuO}$

The XRD patterns of the samples with $\mathrm{Cu}$-rich nominal compositions $\mathrm{Cu}_{1-\mathrm{x}} \mathrm{Co}_{\mathrm{x}} \mathrm{O}_{1+\delta}$ $(0.00 \leq x \leq 0.06)$ are shown in Fig. 1 . They reveal a single phase up to $x=0.04$ with progressive shift of most reflections as the Co content is increased. The lattice parameters are listed in Table 1 . The $\beta$ angle and the c-axis length are not changing significantly, contrary to the $\mathrm{a}$ and $\mathrm{b}$ lattice parameters. The variation of these last two is illustrated in Fig. 2. While the a-axis length increases, the b-axis length decreases and both reach a constant value when impurity phases appear in the XRD patterns. From these data, it can be estimated that the solubility limit of $\mathrm{Co}$ in the tenorite $\mathrm{CuO}$ lattice is situated between 4 at. $\%$ and 5 at. $\%$ of $\mathrm{Cu}$, probably closer to 4 at.\%. This supports the results of Zabdyr and Fabrichnaya [22].

For $0.05 \leq \mathrm{x} \leq 0.64$, the $\mathrm{Cu}_{0.96} \mathrm{Co}_{0.04} \mathrm{O}_{1+\delta}$ composition is in equilibrium with the rock-salt $\mathrm{Cu}-\mathrm{Co}-\mathrm{O}$ solid solution. The upper solubility limit of $\mathrm{Cu}$ in the latter phase corresponds to $36 \pm 2$ at.\% substitution for $\mathrm{Co}$, in close correspondence to the values published by Driessens et al. [20] ( $\approx 33$ at.\%) as well as Zabdyr and Fabrichnaya [22] $\left(\approx 38\right.$ at.\%) at $900^{\circ} \mathrm{C}$. As illustrated in Fig.3, the rock-salt solid-solution extends from $\mathrm{x} \approx 0.65$ to $\mathrm{x} \approx 0.92$ in $\mathrm{Cu}_{1-\mathrm{x}} \mathrm{Co}_{\mathrm{x}} \mathrm{O}_{1+\delta}$. The cubic lattice parameter of this solid solution (Table 1) is not dependant on the $\mathrm{Cu}$ :Co ratio within the accuracy of the calculations. For Co-rich compositions, a two-phase equilibrium appears at $\mathrm{x} \approx 0.94$ in $\mathrm{Cu}_{1}$ ${ }_{\mathrm{x}} \mathrm{Co}_{\mathrm{x}} \mathrm{O}_{1+\delta}$, involving the rock-salt solid-solution and a cubic-spinel $\mathrm{Co}_{3-\mathrm{y}} \mathrm{Cu}_{\mathrm{y}} \mathrm{O}_{4+\delta}$ phase. This is in agreement with the data of Driessens et al. [20] for the temperature of $900^{\circ} \mathrm{C}$, although these authors reported a significantly lower $\mathrm{x}$ value for the 
transition between the two-phase equilibrium and the single rock-salt solid-solution ( 0.83 versus $\approx 0.94$ in the present work. Close to the pure cobalt oxide edge, Driessens et al. [20] reported $\mathrm{Cu}$ solubility up to 9 at.\% for Co in the cubic-spinel phase at about $865^{\circ} \mathrm{C}$, which decreases for increasing temperature and amounts to $1-2$ at. $\%$ at $900^{\circ} \mathrm{C}$. In the present study the presence of a tiny single-phase field in the Co-rich corner could be confirmed by comparing the XRD patterns of samples with $\mathrm{Co}_{98} \mathrm{Cu}_{1} \mathrm{Sr}_{1}$ and $\mathrm{Co}_{96} \mathrm{Cu}_{2} \mathrm{Sr}_{2}$ nominal cation ratio (Fig. 4), which shows the appearance of $\mathrm{Sr}_{6} \mathrm{Co}_{5} \mathrm{O}_{15}$ in the latter sample only. This is further supported by the slight reduction of the unit cell of the $\mathrm{Co}_{3} \mathrm{O}_{4}$ host lattice in the sample with $\left(\mathrm{Co}_{0.99} \mathrm{Cu}_{0.01}\right)_{3} \mathrm{O}_{4-\delta}$ nominal composition (Table 1).

At $900^{\circ} \mathrm{C}$, the $\mathrm{Co}_{3} \mathrm{O}_{4}$ phase was found to be stable, a result which is in good agreement with published temperatures for the $\mathrm{Co}_{3} \mathrm{O}_{4} \leftrightarrow 3 \mathrm{CoO}+0.5 \mathrm{O}_{2}$ equilibrium in air ranging from $897^{\circ} \mathrm{C}$ to $920^{\circ} \mathrm{C}[20,24,39-42]$.

(3) $\mathrm{CoO}_{x}-\mathrm{SrO}$

After equilibration at $900^{\circ} \mathrm{C}$ for a total of $145 \mathrm{~h}$, the sample with $\mathrm{SrCoO}_{3-\mathrm{x}}$ nominal composition was found to consist of a mixture of $\mathrm{Sr}_{6} \mathrm{Co}_{5} \mathrm{O}_{15}$ and $\mathrm{Co}_{3} \mathrm{O}_{4}$, confirming the results published in $[20,22,24,27]$. Similarly, the $\mathrm{Sr}_{3} \mathrm{Co}_{2} \mathrm{O}_{6.33}$ nominal composition resulted in a two-phase sample containing $\mathrm{Sr}_{14} \mathrm{Co}_{11} \mathrm{O}_{33}$ and $\mathrm{SrO}$, supporting the fact that $\mathrm{Sr}_{3} \mathrm{Co}_{2} \mathrm{O}_{6.33}$ is only stable above $900^{\circ} \mathrm{C}$ [24]. A similar result was obtained for the $\mathrm{Sr}_{4} \mathrm{Co}_{3} \mathrm{O}_{9}$ nominal composition. In contrast, both the $\mathrm{Sr}_{6} \mathrm{Co}_{5} \mathrm{O}_{15}$ and the $\mathrm{Sr}_{14} \mathrm{Co}_{11} \mathrm{O}_{33}$ phases were formed at $900^{\circ} \mathrm{C}$. These compounds correspond to the $\alpha: \beta=3: 3$ and 9:5 members of the $\left(\mathrm{A}_{3} \mathrm{Co}_{2} \mathrm{O}_{6}\right)_{\alpha}\left(\mathrm{A}_{3} \mathrm{Co}_{3} \mathrm{O}_{9}\right)_{\beta}$ family in the notation of Boulahya et al. [30]. Two samples with compositions intermediate between $\mathrm{Sr}_{14} \mathrm{Co}_{11} \mathrm{O}_{33}$ (= $\mathrm{Sr}_{6.36} \mathrm{Co}_{5} \mathrm{O}_{15+\delta}$ ) and $\mathrm{Sr}_{6} \mathrm{Co}_{5} \mathrm{O}_{15}$ (i.e. $\mathrm{Sr}_{6.25} \mathrm{Co}_{5} \mathrm{O}_{15+\delta}$ and $\mathrm{Sr}_{6.13} \mathrm{Co}_{5} \mathrm{O}_{15+\delta}$ ) have been prepared to assess the presence of a two-phase equilibria between those 2 compositions. Fig. 5 shows a detail of the XRD pattern of these samples and of those 
with $\mathrm{Sr}_{14} \mathrm{Co}_{11} \mathrm{O}_{33}$ as well as $\mathrm{Sr}_{6} \mathrm{Co}_{5} \mathrm{O}_{15}$ compositions after equilibration at $900^{\circ} \mathrm{C}$ and air quenching. This $2 \theta$ interval contains one of the most intense, non-overlapping reflections of the $\mathrm{Sr}_{14} \mathrm{Co}_{11} \mathrm{O}_{33}$ and $\mathrm{Sr}_{6} \mathrm{Co}_{5} \mathrm{O}_{15}$ XRD patterns. From this figure, it can be concluded that there is in fact a single-phase solid solution region between the $\mathrm{Sr}_{14} \mathrm{Co}_{11} \mathrm{O}_{33}$ and $\mathrm{Sr}_{6} \mathrm{Co}_{5} \mathrm{O}_{15}$ compositions, because the intermediate nominal stoichiometries do not result in superposition of the two individual diffraction patterns. Instead, a progressive shift of the reflection appears, with intermediate values for the $\mathrm{Sr}_{6.25} \mathrm{Co}_{5} \mathrm{O}_{15+\delta}$ and $\mathrm{Sr}_{6.13} \mathrm{Co}_{5} \mathrm{O}_{15+\delta}$ compositions and therefore variations of the lattice parameters. This seems at first sight to contradict the results of Jankovský et al. [24], who found a two-phase region between two crystallographically distinct stoichiometric compounds: $\mathrm{Sr}_{14} \mathrm{Co}_{11} \mathrm{O}_{33}$ and $\mathrm{Sr}_{6} \mathrm{Co}_{5} \mathrm{O}_{15}$. This discrepancy is however only apparent. There is indeed a significant difference in the preparation conditions between the present work, where the samples were rapidly cooled by air-quenching and the study of Jankovský et al. [24], who performed slow cooling at $1^{\circ} \mathrm{C} / \mathrm{min}$.

In order to demonstrate that the processing conditions have a non-negligible influence on phase equilibria in this area of the pseudo-binary $\mathrm{CoO}_{\mathrm{x}}-\mathrm{SrO}$ system, the $\mathrm{Sr}_{6.13} \mathrm{Co}_{5} \mathrm{O}_{15+\delta}$ sample was post-annealed at $600^{\circ} \mathrm{C}$ for $60 \mathrm{~h}$ and furnace cooled. Fig. 6 shows that the full width at half maximum of the XRD peak centred at $44.2^{\circ}$ in this sample after initial equilibration at $900^{\circ} \mathrm{C}$ and air-quenching, has increased from $0.23^{\circ}$ (initial state, XRD pattern a in Fig.6) to $0.35^{\circ}$ after the post-annealing treatment at $600^{\circ} \mathrm{C}$ (XRD pattern b in Fig. 6). Furthermore, we note a splitting of the (208) and (205) reflexions belonging to the $\mathrm{Sr}_{14} \mathrm{Co}_{11} \mathrm{O}_{33}$ and $\mathrm{Sr}_{6} \mathrm{Co}_{5} \mathrm{O}_{15}$ phases respectively after annealing at $600^{\circ} \mathrm{C}$. A peak displacement and separation into two reflections ((128) and (125) from $\mathrm{Sr}_{14} \mathrm{Co}_{11} \mathrm{O}_{33}$ and $\mathrm{Sr}_{6} \mathrm{Co}_{5} \mathrm{O}_{15}$ respectively) is also observed. This shows that a two-phase equilibrium has been achieved. However, performing a new 
annealing at $900^{\circ} \mathrm{C}$ on the same sample and cooling it fast by air-quenching restores the initial XRD pattern. It can thus be concluded that at $900^{\circ} \mathrm{C}$, there is a continuous solid-solution between the $\mathrm{Sr}_{14} \mathrm{Co}_{11} \mathrm{O}_{33}$ and $\mathrm{Sr}_{6} \mathrm{Co}_{5} \mathrm{O}_{15}$ compositions (that shall be denoted as $\operatorname{Sr}_{6+\mathrm{x}} \mathrm{Co}_{5} \mathrm{O}_{15+\delta}(0 \leq \mathrm{x} \leq 0.36$ in the following $)$, whereas a two-phase equilibrium reflects a lower temperature state. A phase separation must thus take place at a temperature lower than $900^{\circ} \mathrm{C}$.

As will be shown in the next sub-section, this binary solid-solution extends into the ternary diagram by admitting $\mathrm{Cu}$ substitution and will be denoted as $\mathrm{Sr}_{6+\mathrm{x}} \mathrm{Co}_{5}$ ${ }_{\mathrm{y}} \mathrm{Cu}_{\mathrm{y}} \mathrm{O}_{15+\delta}$.

(4) $\mathrm{CoO}_{x}-\mathrm{CuO}-\mathrm{SrO}$

The tie-line compatibilities of phases in the $\mathrm{CoO}_{\mathrm{x}}-\mathrm{CuO}-\mathrm{SrO}$ system at $900^{\circ} \mathrm{C}$ are shown in Fig.7. This pseudo-ternary section consists of 6 three-phase regions and 6 two-phase fields. There are 2 solid solutions extending into the ternary system. The $\mathrm{Sr}_{6+\mathrm{x}} \mathrm{Co}_{5-\mathrm{y}} \mathrm{Cu}_{\mathrm{y}} \mathrm{O}_{15+\delta}$ solid solution dominates the system by being in equilibrium with all other phases and involved in most two-phase and three-phase fields.

There is no evidence for sizable Co solubility in $\mathrm{Sr}_{2} \mathrm{CuO}_{3}$ and $\mathrm{SrCuO}_{2}$ under the present processing conditions. In contrast, $\mathrm{Co}$ can be substituted for $\mathrm{Cu}$ in the $\mathrm{Sr}_{14} \mathrm{Cu}_{24} \mathrm{O}_{41-\delta}$ phase. Fig.8 shows the XRD patterns of the samples with $\mathrm{Sr}_{14} \mathrm{Cu}_{24}$ ${ }_{\mathrm{x}} \mathrm{Co}_{\mathrm{x}} \mathrm{O}_{41-\delta}(\mathrm{x}=0 ; 5$ and 6$)$ nominal compositions. Up to $\mathrm{x}=5$, the samples exhibit a single phase diffraction pattern with displacement of the peak positions towards higher angles. However, reflections belonging to $\mathrm{CuO}$ and the $\mathrm{Sr}_{6+\mathrm{x}} \mathrm{Co}_{5-\mathrm{y}} \mathrm{Cu}_{\mathrm{y}} \mathrm{O}_{15+\delta}$ solid-solution appear for the $\mathrm{Sr}_{14} \mathrm{Cu}_{18} \mathrm{Co}_{6} \mathrm{O}_{41-\delta}$ nominal stoichiometry. The lattice parameters of the $\mathrm{Sr}_{14} \mathrm{Cu}_{24-\mathrm{x}} \mathrm{Co}_{\mathrm{x}} \mathrm{O}_{41-\delta}$ phase are listed in Table 1 and plotted in Fig.9. These data show that the solubility limit of Co in the $\mathrm{Sr}_{14} \mathrm{Cu}_{24} \mathrm{O}_{41-\delta}$ lattice is in fact close to $\mathrm{Sr}_{14} \mathrm{Cu}_{19} \mathrm{Co}_{5} \mathrm{O}_{41-\delta}$. Low temperature resistivity measurements performed on the samples with $\mathrm{Sr}_{14} \mathrm{Cu}_{24} \mathrm{O}_{41-\delta}$ and $\mathrm{Sr}_{14} \mathrm{Cu}_{19} \mathrm{Co}_{5} \mathrm{O}_{41-\delta}$ compositions (Fig. 10) show that 
Co doping results in a lowering of the resistivity by nearly 2 orders of magnitude. Nevertheless, even the maximum Co content is not enough to induce a metallic behaviour. This confirms the results published by Yoshimitsu et al. [31].

The lattice parameters of a series of samples with $\mathrm{Sr}_{6.25} \mathrm{Co}_{5-\mathrm{y}} \mathrm{Cu}_{\mathrm{y}} \mathrm{O}_{15+\delta}$ nominal compositions are listed in Table 1 and plotted in Fig. 11). Their behaviour shows that up to about 22 at.\% $\mathrm{Cu}$ can be introduced. Furthermore, the presence of a solidsolution rather than a two-phase equilibrium between $\mathrm{Sr}_{6} \mathrm{Co}_{5-\mathrm{x}} \mathrm{Cu}_{\mathrm{x}} \mathrm{O}_{15-\delta}$ and $\mathrm{Sr}_{14} \mathrm{Co}_{11-}$ ${ }_{\mathrm{x}} \mathrm{Cu}_{\mathrm{x}} \mathrm{O}_{33-\delta}$ all the way up to the $\mathrm{Cu}$ solubility limit is evidenced by the single reflection around $44.2^{\circ}$ in the XRD patterns of samples with $\mathrm{Sr}_{6+\mathrm{x}} \mathrm{Co}_{5-\mathrm{y}} \mathrm{Cu}_{\mathrm{y}} \mathrm{O}_{15+\delta}$ compositions $(0 \leq \mathrm{x} \leq 0.36 ; 0 \leq \mathrm{y} 1.0)$ as illustrated in Fig. 12). Electrical resistivity measurements show that the $\mathrm{Sr}_{6+\mathrm{x}} \mathrm{Co}_{5} \mathrm{O}_{15+\delta}$ solid-solution is characterised by a semi-conducting behaviour similarly to data published for the undoped $\mathrm{Sr}_{5} \mathrm{Co}_{4} \mathrm{O}\left(=\mathrm{Sr}_{6.25} \mathrm{Co}_{5} \mathrm{O}_{15+\delta}\right)$ [28], while $\mathrm{Cu}$ doping results in a clear increase of the resistivity (Fig.10).

Defining the range of $\delta$ values in these two solid solutions is not straightforward. For $\mathrm{Sr}_{6+\mathrm{x}} \mathrm{Co}_{5-\mathrm{y}} \mathrm{Cu}_{\mathrm{y}} \mathrm{O}_{15+\delta}$, assuming a $\delta=0$ in $\mathrm{Sr}_{6} \mathrm{Co}_{5} \mathrm{O}_{15}$ gives an average valency of +1.8 for Co. Rewriting this composition as $\left(\mathrm{Sr}_{3} \mathrm{Co}_{2} \mathrm{O}_{6}\right)_{3}\left(\mathrm{Sr}_{3} \mathrm{Co}_{3} \mathrm{O}_{9}\right)_{3}$ [30], it can be realized that the change in oxygen content resulting from the substitution of $\mathrm{Cu}$ will depend on the distribution of this element in the two non-equivalent Co sites. If all substituting $\mathrm{Cu}$ atoms are in the +2 oxidation state, as expected at $900^{\circ} \mathrm{C}$ in air, for the maximum solubility of $\mathrm{y}=1.0$ in $\mathrm{Sr}_{6+\mathrm{x}} \mathrm{Co}_{5-\mathrm{y}} \mathrm{Cu}_{\mathrm{y}} \mathrm{O}_{15+\delta}$, the overall oxygen content will decrease by $\delta=-0.75$ at least and by $\delta=-1.0$ at most. Since the $\operatorname{Sr}(2+)$ content in this phase can vary between $\mathrm{x}=0$ and $\mathrm{x}=0.36$, it can be estimated that $\delta$ can vary between $+0.36(\mathrm{x}=0.36, \mathrm{y}=0)$ and $-1.0(\mathrm{x}=0, \mathrm{y}=1.0)$. For the $\mathrm{Sr}_{14} \mathrm{Cu}_{24-\mathrm{x}} \mathrm{Co}_{\mathrm{x}} \mathrm{O}_{41-\delta}$ solid solution, the situation is more intricate, because " $\mathrm{Sr}_{14} \mathrm{Cu}_{24} \mathrm{O}_{41-\delta}$ " corresponds in fact to an average cell made of the incommensurate superposition of $\mathrm{CuO}_{2}$ and $\mathrm{Sr}_{2} \mathrm{Cu}_{2} \mathrm{O}_{3}$ planes, with $\mathrm{Cu}$ in an average oxidation state greater than +2 [43]. The 
effect of Co substitution on the oxygen content of this phase and thus on $\delta$ probably depends on the $\mathrm{Cu}$ sites (chains or ladders) on which Co substitutes. A realistic estimation of the $\delta$ range for the $\mathrm{Sr}_{14} \mathrm{Cu}_{24-\mathrm{x}} \mathrm{Co}_{\mathrm{x}} \mathrm{O}_{41-\delta}$ solid solution will require specific measurements and/or accurate refinement of XRD diffraction patterns, which are beyond the scope of the present work.

\section{(5) Comparison with related systems}

Few systems including $\mathrm{SrO}, \mathrm{CoO}_{\mathrm{x}}$ and a transition metal oxide have been assessed. At $900^{\circ} \mathrm{C}$, Fossdal et al. [44] only found $\mathrm{SrCoO}_{3-\delta}$ as binary Sr-Co oxide phase in air. It forms a complete solid solution by substitution of $\mathrm{Fe}$ for Co up to $\mathrm{SrFeO}_{3-\delta}$. In contrast, in the same system but at $1100^{\circ} \mathrm{C}$ in air, Aksenova et al. [45] report Fe solubility neither in $\mathrm{SrCoO}_{2.5}$ nor in $\mathrm{Sr}_{3} \mathrm{Co}_{2} \mathrm{O}_{7}$. This is different to the case of the $\mathrm{CoO}_{\mathrm{x}}-\mathrm{NiO}-\mathrm{SrO}$ phase equilibria at $1100^{\circ} \mathrm{C}$ in air, where $\mathrm{Ni}$ can be substituted for Co up to 15 at $\%$ in $\mathrm{SrCoO}_{2,5+\delta}$ and 55 at. $\%$ in $\mathrm{Sr}_{3} \mathrm{Co}_{2} \mathrm{O}_{7-\delta}$ [46]. $\mathrm{SrCoO}_{\mathrm{x}}$ was also the only binary Sr-Co oxide phase reported by Surat et al. [47] at 600C in a study of the $\mathrm{CoO}_{\mathrm{x}}-\mathrm{SrO}-\mathrm{V}_{2} \mathrm{O}_{5}$ system. No vanadium can be introduced in $\mathrm{SrCoO}_{\mathrm{x}}$. In contrast to transition metal elements, which tend to substitute for Co in Sr-Co oxide phases, lanthanides appear to preferentially substitute for $\mathrm{Sr}$, as shown e.g. by Volkova et al. [47] in the $\mathrm{Sm}_{2} \mathrm{O}_{3}-\mathrm{SrO}-\mathrm{CoO}$ system.

An isothermal section of the $\mathrm{CaO}-\mathrm{CoO}_{x}-\mathrm{CuO}$ system at $920^{\circ} \mathrm{C}$ was published by Miyazaki et al. [49]. It shows a ternary oxide phase with $\left[\mathrm{Ca}_{2}\left(\mathrm{Co}_{0.65} \mathrm{Cu}_{0.35}\right)_{2} \mathrm{O}_{4}\right]_{0.62} \mathrm{CoO}_{2}$ composition, which has no Sr-equivalent in the $\mathrm{CoO}_{\mathrm{x}}$ $-\mathrm{CuO}-\mathrm{SrO}$ system at $900^{\circ} \mathrm{C}$ in air. Both $\mathrm{Ca}-\mathrm{Co}$ binary oxide phases that are stable in pure $\mathrm{O}_{2}$ at $920^{\circ} \mathrm{C}$ admit some $\mathrm{Cu}$ substitution for $\mathrm{Co}: 6$ at.\% in $\mathrm{Ca}_{3} \mathrm{Co}_{2} \mathrm{O}_{6}$ and 12 at. $\%$ in $\left[\mathrm{Ca}_{2} \mathrm{CoO}_{3}\right]_{\mathrm{p}} \mathrm{CoO}_{2}$.

The $\mathrm{CoO}_{\mathrm{x}}-\mathrm{CuO}-\mathrm{BaO}$ system doesn't seem to have been explored in details but might be more complicated than the $\mathrm{CoO}_{\mathrm{x}}-\mathrm{CuO}-\mathrm{SrO}$ and $\mathrm{CaO}-\mathrm{CoO}_{\mathrm{x}}-\mathrm{CuO}$ 
systems in view of the numerous binary-oxide phases that are stable in the $\mathrm{CuO}-$ $\mathrm{BaO}$ pseudo-binary system in the $800^{\circ} \mathrm{C}-1000^{\circ} \mathrm{C}$ temperature range $[50,51]$.

\section{Summary}

The subsolidus relationship and phase formation of compounds in the $\mathrm{CoO}_{\mathrm{x}}-\mathrm{CuO}$ - $\mathrm{SrO}$ system were established at $900^{\circ} \mathrm{C}$ in air. The pseudo-ternary phase diagram is divided into 6 three-phase regions and 6 two-phase fields. No ternary oxide phase was found. Instead, two binary phases extend into the ternary system forming solid solutions. One is based on the $\mathrm{Sr}_{14} \mathrm{Cu}_{24} \mathrm{O}_{41-\delta}$ phase, in which up to 20 at.\% $\mathrm{Cu}$ can be replaced by Co, which induces a significant decrease of the electrical resistivity, however without resulting in a transition to a metallic behaviour. The other can be described as $\mathrm{Sr}_{6+\mathrm{x}} \mathrm{Co}_{5-\mathrm{y}} \mathrm{Cu}_{\mathrm{y}} \mathrm{O}_{15+\delta}(0 \leq \mathrm{x} \leq 0.36 ; 0 \leq \mathrm{y} \leq 1.0$, with $-1.00 \leq \delta \leq 0.36)$. In that case, the introduction of $\mathrm{Cu}$ into the host $\mathrm{Sr}_{6+\mathrm{x}} \mathrm{Co}_{5} \mathrm{O}_{15+\delta}$ lattice results in an increase of the electrical resistivity. Annealing a sample with $\operatorname{Sr}_{6.13} \mathrm{Co}_{5} \mathrm{O}_{15+\delta}$ composition (i.e. within the $\mathrm{Sr}_{6+\mathrm{x}} \mathrm{Co}_{5} \mathrm{O}_{15+\delta}$ solid solution range) at $600^{\circ} \mathrm{C}$ followed by slow cooling resulted in a phase separation into $\mathrm{Sr}_{14} \mathrm{Co}_{11} \mathrm{O}_{33}$ and $\mathrm{Sr}_{6} \mathrm{Co}_{5} \mathrm{O}_{15}$. The processing conditions thus appear to have a strong effect on the phase equilibria in the $\mathrm{CoO}_{\mathrm{x}}-\mathrm{CuO}-\mathrm{SrO}$ system, because the $\mathrm{Sr}_{6+\mathrm{x}} \mathrm{Co}_{5-\mathrm{y}} \mathrm{Cu}_{\mathrm{y}} \mathrm{O}_{15+\delta}$ solid solution is involved in most two-phase and three-phase fields so that slow cooling may affect the topology of a significant area of the system.

\section{Acknowledgements}

This work was supported by the Danish Technical Research Council under the Framework Programme on Superconductivity. 


\section{References}

[1] J.G. Bednorz and K.A. Muller, Possible high- $\mathrm{T}_{\mathrm{c}}$ superconductivity in the BaLa-Cu-O system, Zeitschrift fûr Physik B 64 (1986) 189 - 193

[2] J.C. Grivel, Subsolidus phase relations of the $\mathrm{CaO}-\mathrm{REO}_{\mathrm{x}}-\mathrm{CuO}$ systems $(\mathrm{RE}=\mathrm{Eu}, \mathrm{Tb}, \mathrm{Dy}, \mathrm{Ho}, \mathrm{Er}, \mathrm{Lu}$ and $\mathrm{Sc})$ at $900^{\circ} \mathrm{C}$ in air, J. Phase Equilibria and Diffusion 37 (2016) $601-610$

[3] V.D. Zhuravlev, Y.A. Velikodnyi and L.V. Kristallov, Study of phase-equilibria in the $\mathrm{CuO}-\mathrm{SrO}-\mathrm{V}_{2} \mathrm{O}_{5}$ system, Zh. Neorg. Khim. 32 (1987) 3060 - 3063

[4] N.M. Drozdova, V.P. Sirotinkin and A.A. Evdokimov, Phase correlations in subsolidus domain of $\mathrm{SrO}-\mathrm{CuO}-\mathrm{Nb}_{2} \mathrm{O}_{5}$ system, Zh. Neorg. Khim. 36 (1991) 1588 $-1589$

[5] V.P. Sirotinkin and N.M. Drozdova, Phase relations in $\mathrm{SrO}-\mathrm{CuO}-\mathrm{Nb}_{2} \mathrm{O}_{5}$ system in the spectrum with high strontium oxide content, Zh. Neorg. Khim. 38 (1993) 1912 $-1913$

[6] L.T. Yang, J.K. Liang, G.B. Song, H. Chang and G.H. Rao, Compounds and phase relations in the $\mathrm{SrO}-\mathrm{Fe}_{2} \mathrm{O}_{3}-\mathrm{CuO}, \mathrm{SrO}-\mathrm{Fe}_{2} \mathrm{O}_{3}-\mathrm{Gd}_{2} \mathrm{O}_{3}$ and $\mathrm{Gd}_{2} \mathrm{O}_{3}-\mathrm{Fe}_{2} \mathrm{O}_{3}-\mathrm{CuO}$ ternary systems, J. Alloys Comp. 353 (2003) $301-306$

[7] S.-Y. Lee, H.E. Kim and S.-I. Yoo, Subsolidus phase relations in the $\mathrm{SrO}-\mathrm{CuO}-$ $\mathrm{TiO}_{2}$ ternary system at $950^{\circ} \mathrm{C}$ in air, J. Alloys Comp. 556 (2013) $210-213$

[8] J.-C. Grivel, Subsolidus phase relations of the $\mathrm{SrO}-\mathrm{MO}_{2}-\mathrm{CuO}$ systems $(\mathrm{M}=\mathrm{Ti}$, $\mathrm{Zr}$ and Hf) at $900^{\circ} \mathrm{C}$ in air, J. Alloys Comp. 464 (2008) $457-460$

[9] J.-C. Grivel, Subsolidus phase relations of the $\mathrm{SrO}-\mathrm{Ta}_{2} \mathrm{O}_{5}-\mathrm{CuO}$ system at $900^{\circ} \mathrm{C}$ in air, J. Alloys. Comp. 486 (2009) 293 - 298

[10] J.-C. Grivel, Subsolidus phase relations of the $\mathrm{SrO}-\mathrm{WO}_{3}-\mathrm{CuO}$ system at $800^{\circ} \mathrm{C}$ in air, J. Alloys Comp. 513 (2012) 304 - 309 
[11] H. Maeda, Y. Tanaka, M. Fukutomi, T. Asano, K. Togano, H. Kumakura, M. Uehara, S. Ikeda, K. Ogawa, S. Horiuchi and Y. Matsui, New high- $T_{\mathcal{c}}$ superconductors without rare-earth element, Physica C 153-155 (1988) 602 - 607

[12] Z.Z. Sheng and A.M. Hermann, Bulk superconductivity at $120 \mathrm{~K}$ in the $\mathrm{Tl}-\mathrm{Ca} / \mathrm{Ba}-\mathrm{Cu}-$ O system, Nature 332 (1988) 138 - 139

[13] J.K. Liang, C. Zhan, W. Fei, S.S. Xie, Phase-diagram of $\mathrm{SrO}-\mathrm{CaO}-\mathrm{CuO}$ ternary-system, Solid State Commun., 1990, 75, p 247-252

[14] A.S. Kosmynin, B.V. Slobodin, V.L. Balashov, I.K. Garkushin, A.A. Fotiev and A.S. Trunin, Phase-equilibria in the $\mathrm{CaO}-\mathrm{SrO}-\mathrm{CuO}$ system $(\geq 70 \mathrm{~mol} \%$ CuO), Inorg. Mater., 1995, 7, p 867-870

[15] N.M. Hwang, R.S: Roth, C.J. Rawn, Phase-equilibria in the systems SrO-CuO and $\mathrm{SrO}-1 / 2 \mathrm{Bi}_{2} \mathrm{O}_{3}$, J. Am. Ceram. Soc., 1990, 73, p 2531-2533

[16] R.O. Suzuki, P. Bohac, L.J. Gauckler, Thermodynamics and phase-equilibria in the Sr-Cu-O system, J. Am. Ceram. Soc., 1992, 75, p 2833-2842

[17] M. Nevriviva, H. Kraus, Study of phase-equilibria in the partially open $\mathrm{Sr}-\mathrm{Cu}-$ (O) system, Physica C, 1994, 235-240, p 325-326

[18] C.B. Alcock, B.Z. Li, Thermodynamic study of the Cu-Sr-O system, J. Am. Ceram. Soc., 1990, 73, p 1176-1180

[19] N. Kobayashi, Z. Hiroi and M. Takano, Compounds and phase relations in the SrO-CaO-CuO system under high pressure J. Sol. State Chem. 132 (1997) 274 $-283$

[20] F.C.M. Driessens, G.D. Rieck and H.N. Coenen, Phase equilibria in the system cobalt oxide/copper oxide in air, J. inorg. nucl. Chem. 30 (1968) 747 753 
[21] C. Landolt and A. Muan, Activity-composition relations in $\mathrm{CuO}-\mathrm{CoO}$ solid solutions as determined from equilibria in the system $\mathrm{Cu}-\mathrm{Co}-\mathrm{O}$, J. Inorg. Nucl. Chem. 31 (1969) 1319 - 1326

[22] L.A. Zabdyr and O.B. Fabrichnaya, Phase equilibria in the cobalt oxide copper oxide system, J. Phase Equilibria 23 (2002) 149 - 155

[23] L.A. Zabdyr and O.B. Fabrichnaya, Phase equilibria in the $\mathrm{Co}-\mathrm{Cu}-\mathrm{O}-\mathrm{Si}$ system, Computer Coupling of Phase Diagrams and Thermochemistry 28 (2004) $293-298$

[24] O. Jankovský, D. Sedmidubský, J. Vítek, P. Šimek and Z. Sofer, Phase diagram of the Sr-Co-O system, J. Eur. Ceram. Soc. 35 (2015) 935 - 940

[25] J.-C. Grenier, S. Ghodbane, G. Demazeau, M. Pouchard and P. Hagenmuller, Strontium cobaltite, $\mathrm{Sr}_{2} \mathrm{Co}_{2} \mathrm{O}_{5}-$ characterization and magnetic-properties, Mat. Res. Bull. 14 (1979) 831 - 839

[26] J. Rodríguez and J.M. González-Calbet, Rhombohedral $\mathrm{Sr}_{2} \mathrm{Co}_{2} \mathrm{O}_{5}-\mathrm{A}$ new $\mathrm{A}_{2} \mathrm{M}_{2} \mathrm{O}_{5}$ phase, Mat. Res. Bull. 21 (1986) 429 - 439

[27] W.T.A. Harrison, S.L. Hegwood and A.J. Jacobson, A powder neutrondiffraction determination of the structure of $\mathrm{Sr}_{6} \mathrm{Co}_{5} \mathrm{O}_{15}$, formerly described as the low-temperature hexagonal form of $\mathrm{SrCoO}_{3-\mathrm{x}}$, J. Chem. Soc. Chem. Commun. (1995) $1953-1954$

[28] T. Takami, H. Ikuta and U. Mizutani, Thermoelectric properties of $\mathrm{A}_{\mathrm{n}+2} \mathrm{Co}_{\mathrm{n}+1} \mathrm{O}_{3 \mathrm{n}+3}(\mathrm{~A}=\mathrm{Ca}, \mathrm{Sr}, \mathrm{Ba}, \mathrm{n}=1-5)$, Jpn. J. Appl. Phys. 43 (2004) $8208-$ 8212

[29] R. Christoffersen, A.J. Jacobson, S.L. Hegwood and L. Liu, New onedimensional commensurate and incommensurate structural forms of $\mathrm{Sr}-\mathrm{Co}$ oxide, Solid-State Chemistry of Inorganic Materials 453 (1997) 153 - 158 
[31] K. Boulahya, M. Parras and J.M. González-Calbet, New commensurate phases in the family $\left(\mathrm{A}_{3} \mathrm{Co}_{2} \mathrm{O}_{6}\right)_{\alpha}\left(\mathrm{A}_{3} \mathrm{Co}_{3} \mathrm{O}_{9}\right)_{\beta}(\mathrm{A}=\mathrm{Ca}, \mathrm{Sr}, \mathrm{Ba})$, Chem. Mater. $12(2000) 25-32$

[32] H. Yoshimitsu, M. Hiroi and M. Kawakami, Substitution effects of cobalt on the electrical resistivity of $\mathrm{Sr}_{14} \mathrm{Cu}_{24} \mathrm{O}_{41}$, Physica B 329 (2003) $1016-1017$

[33] K. Karmakar, A. Singh, S. Singh, A. Poole and C. Rüegg, Crystal growth of the nonmagnetic $\mathrm{Zn}^{2+}$ and magnetic $\mathrm{Co}^{2+}$ doped quasi-one-dimensional spin chain compound $\mathrm{SrCuO}_{2}$ using the traveling solvent floating zone method, Crystal Growth \& Design 14 (2014) $1184-1192$

[34] J.-C. Grivel and K. Thyden, Subsolidus phase relations of the $\mathrm{SrO}-\mathrm{In}_{2} \mathrm{O}_{3}-$ $\mathrm{CuO}$ system in air, J. Phase Equilibria and Diffusion 34 (2013) 89 - 93

[35] J.-C. Grivel and N.H. Andersen, Subsolidus phase relations of the $\mathrm{SrO}-$ $\mathrm{REO}_{\mathrm{x}}-\mathrm{CuO}$ systems $(\mathrm{RE}=\mathrm{Ce}, \mathrm{Pr}$ and Tb), J. Alloys Compd. 436 (2007) 261 $-265$

[36] J.-C. Grivel and N.H. Andersen, Subsolidus phase relations of the SrO $\mathrm{RE}_{2} \mathrm{O}_{3}-\mathrm{CuO}$ systems $(\mathrm{RE}=\mathrm{Tm}, \mathrm{Lu}$ and $\mathrm{Sc}), \mathrm{J}$. Alloys Compd. 391 (2005) $292-295$

[37] J.-C. Grivel and N.H. Andersen, Subsolidus phase relations of the $\mathrm{SrO}-$ $\mathrm{Er}_{2} \mathrm{O}_{3}-\mathrm{CuO}$ system, J. Alloys Compd. 389 (2005) $186-189$

[38] W. Wong-Ng, Q. Huang, I. Levin, J.A. Kaduk, J. Dillingham, T. Haugan, J. Suh and L.P. Cook, Crystal chemistry and phase equilibria of selected $\mathrm{SrO}-$ $\mathrm{R}_{2} \mathrm{O}_{3}-\mathrm{CuO}$ and related systems; $\mathrm{R}=$ lanthanides and yttrium, Int. J. Inorg. Mater. 3 (2001) 1283 - 1290

[39] S.G. Popov, Y.Y. Skolis, F.M. Putilina and L.I. Khramtsova, Phase-equilibria in $\mathrm{SrO}-\mathrm{CaO}-\mathrm{CuO}$ system at $1173 \mathrm{~K}$, Zh. Neorg. Khimii 37 (1992) $2598-$ 2605 
[39] E. Aukrust and A. Muan, Thermodynamic properties of solid solutions with spinel-type structure I System $\mathrm{Co}_{3} \mathrm{O}_{4}-\mathrm{Mn}_{3} \mathrm{O}_{4}$, Trans. Metal. Soc. AIME 230 (1964) $378-380$

[40] O.M. Sreedharan, M.S. Chandrasekharaiah and M.D. Karkhanavala, Thermodynamic stabilities of cobalt oxides, High Temp. Sci. 9 (1977) 109 118

[41] G.M. Kale, S.S. Pandit and K.T. Jacob, Thermodynamics of cobalt(II,III) oxide $\left(\mathrm{Co}_{3} \mathrm{O}_{4}\right)$ - Evidence of phase-transition, Trans. Japan Inst. Met. 29 (1988) $125-132$

[42] M.Chen. B. Hallstedt and L.J. Gauckler, Thermodynamic assessment of the Co-O system, J. Phase Equil. 24 (2003) 212 - 227

[43] E.M. McCarron III, M.A. Subramanian, J.C. Calabrese and R.L. Harlow, The incommensurate structure of $\left(\mathrm{Sr}_{14-\mathrm{x}} \mathrm{Ca}_{\mathrm{x}}\right) \mathrm{Cu}_{24} \mathrm{O}_{41}(0<\mathrm{x} \sim 8)$ a superconductor byproduct, Mater. Res. Bull. 23 (1988) 1355 - 1365

[44] A. Fossdal, L.T. Sagdahl, M.-A. Einarsrud, K. Wiik, P.H. Larsen and F.W. Poulsen, Phase equilibria and microstructure in $\mathrm{Sr}_{4} \mathrm{Fe}_{6-\mathrm{x}} \mathrm{Co}_{\mathrm{x}} \mathrm{O}_{13} 0 \leq \mathrm{x} \leq$ mixed conductors, Sol. St. Ionics 143 (2001) 367 - 377

[45] T.V. Aksenova, L.Ya. Gavrilova and V.A. Cherepanov, Phase equilibria and crystal structure of the complex oxides in the Sr-Fe-Co-O system, J. Sol. St. Chem. 181 (2008) $1480-1484$

[46] M.A. Melkozerova, T.V. Aksenova, L.Ya. Gavrilova and V.A. Cherepanov, Phase equilibria and the structure of individual phases in the $\mathrm{Sr}-\mathrm{Co}-\mathrm{Ni}-\mathrm{O}$ system at $1100^{\circ} \mathrm{C}$ in air, Russ. J. Phys. Chem. 79 (2005) 1197 - 1202

[47] L.L. Surat, Phase relations in $\mathrm{MO}-\mathrm{CoO}-\mathrm{V}_{2} \mathrm{O}_{5}(\mathrm{M}=\mathrm{Ca}, \mathrm{Sr}, \mathrm{Ba})$ mixtures, Russ. J. Inorg. Chem. 44 (1999) 112 - 114 
[48] N.E. Volkova, A.V. Maklarova, L.Ya. Gavrilova and V.A. Cherepanov, Phase equilibria, crystal structure and properties of intermediate oxides in the $\mathrm{Sm}_{2} \mathrm{O}_{3}$ - $\mathrm{SrO}$ - $\mathrm{CoO}$ system, Eur. J. Inorg. Chem. Accepted for publication

[49] Y. Miyazaki, X. Huang and T. Kajitani, Compounds and subsolidus phase relations in the $\mathrm{CaO}-\mathrm{Co}_{3} \mathrm{O}_{4}-\mathrm{CuO}$ system, J. Sol. St. Chem. 178 (2005) $2973-2979$

[50] T.B. Lindemer and E.D. Specht, The $\mathrm{BaO}-\mathrm{Cu}-\mathrm{CuO}$ system - solid-liquid equilibria and thermodynamics of $\mathrm{BaCuO}_{2}$ and $\mathrm{BaCu}_{2} \mathrm{O}_{2}$, Physica $\mathrm{C} 255$ (1995) $81-95$

[51] L.A. Klinkova, Nikolaichik V.I., Barkovskii N.V. and Fedotov V.K., Phase relations in a barium-rich high-temperature region $(25-45 \mathrm{~mol} \% \mathrm{CuO}, 900-$ $1100^{\circ} \mathrm{C}$ ) of the $\mathrm{BaO}^{-\mathrm{CuO}_{\mathrm{x}}}$ system, J. Sol. St. Chem. 184 (2011) $1834-1842$ 


\section{Figure captions}

Figure 1: XRD patterns (detail) of samples with $\mathrm{Cu}_{1-\mathrm{x}} \mathrm{Co}_{\mathrm{x}} \mathrm{O}_{1+\delta}(0.00 \leq \mathrm{x} \leq 0.06)$ nominal compositions. Vertical arrows at the bottom of the figure indicate reflections from $\mathrm{CuO}$.

Figure 2: $\mathrm{a}$ and $\mathrm{b}$ lattice parameters of the tenorite $\mathrm{Cu}_{1-\mathrm{x}} \mathrm{Co}_{\mathrm{x}} \mathrm{O}_{1+\delta}$ solid-solution.

Figure 3: XRD patterns (detail) of samples with nominal compositions within and around the $\mathrm{Cu}_{1-\mathrm{x}} \mathrm{Co}_{\mathrm{x}} \mathrm{O}_{1+\delta}$ rock-salt solid solution.

Figure 4: XRD patterns (detail) of samples with compositions in the Co-rich corner of the pseudo-ternary system.

Figure 5: Detail of the XRD patterns of samples with nominal compositions varying from $\mathrm{Sr}_{6} \mathrm{Co}_{5} \mathrm{O}_{15}$ to $\mathrm{Sr}_{14} \mathrm{Co}_{11} \mathrm{O}_{33}$. This area of the XRD patterns includes several non-overlapping peaks and reveals that there is a solid solution between these two compositions. a: $\mathrm{Sr}_{6} \mathrm{Co}_{5} \mathrm{O}_{15+\delta}$, b: $\mathrm{Sr}_{6.13} \mathrm{Co}_{5} \mathrm{O}_{15+\delta}, \quad$ c: $\mathrm{Sr}_{6.25} \mathrm{Co}_{5} \mathrm{O}_{15+\delta}, \mathrm{d}: \mathrm{Sr}_{6.36} \mathrm{Co}_{5} \mathrm{O}_{15+\delta}\left(=\mathrm{Sr}_{14} \mathrm{Co}_{11} \mathrm{O}_{33}\right)$. The Miller indices correspond to the $\mathrm{Sr}_{6} \mathrm{Co}_{5} \mathrm{O}_{15}$ structure [26]. The shoulder on the high-angle side of the (223) peaks is due to the $K_{\alpha 2}$ radiation, which was not subtracted to avoid possible artefacts that might arise as a result of mathematical manipulation of the data.

Figure 6: Detail of the XRD patterns of a sample with $\mathrm{Sr}_{4.9} \mathrm{Co}_{4} \mathrm{O}_{12-\delta}$ nominal composition after equilibration at $900^{\circ} \mathrm{C}$ and air-quench (a); after further annealing at $600^{\circ} \mathrm{C}$ for $60 \mathrm{~h}$ and furnace cooling (b); final equilibration at $900^{\circ} \mathrm{C}$ for $60 \mathrm{~h}$ and air-quench (c). Miller indices in italic characters refer to the $\mathrm{Sr}_{5} \mathrm{Co}_{4} \mathrm{O}_{12}$ reference XRD pattern [89-8305], whereas Miller indices in normal characters refer to the $\mathrm{Sr}_{6} \mathrm{Co}_{5} \mathrm{O}_{15}$ reference XRD pattern [86-614].

Figure 7: Phase diagram of the $\mathrm{CoO}_{\mathrm{x}}-\mathrm{CuO}-\mathrm{SrO}$ pseudo-ternary system at $900^{\circ} \mathrm{C}$ in air. The studied compositions are marked by symbols: $\bullet=$ single phase, $\bigcirc=$ two phases; $\odot=$ three phases.

Figure 8: $\mathrm{XRD}$ patterns (detail) of the samples with $\mathrm{Sr}_{14} \mathrm{Cu}_{24-\mathrm{x}} \mathrm{Co}_{\mathrm{x}} \mathrm{O}_{41-\delta}(\mathrm{x}=0 ; 5$ and 6) nominal compositions. $\bullet=\mathrm{Sr}_{6+\mathrm{x}} \mathrm{Co}_{5-\mathrm{y}} \mathrm{Cu}_{\mathrm{y}} \mathrm{O}_{15+\delta} ; \boldsymbol{\nabla}=\mathrm{CuO}$.

Figure 9: Lattice parameters of the $\mathrm{Sr}_{14} \mathrm{Cu}_{24-\mathrm{x}} \mathrm{Co}_{\mathrm{x}} \mathrm{O}_{41-\delta}$ phase versus Co-doping level. 
Figure 10: Low temperature electrical resistivity of samples belonging to the $\mathrm{Sr}_{14} \mathrm{Cu}_{24}$ ${ }_{\mathrm{x}} \mathrm{Co}_{\mathrm{x}} \mathrm{O}_{41-\delta}$ solid solution (a) as well as to the $\mathrm{Sr}_{6+\mathrm{x}} \mathrm{Co}_{5-\mathrm{y}} \mathrm{Cu}_{\mathrm{y}} \mathrm{O}_{15+\delta}$ solid solution (b).

Figure 11: Lattice parameters of samples with the $\mathrm{Sr}_{6.25} \mathrm{Co}_{5-\mathrm{y}} \mathrm{Cu}_{\mathrm{y}} \mathrm{O}_{15+\delta}$ nominal compositions.

Figure 12: XRD patterns (detail) of samples with composition lying within the $\mathrm{Sr}_{6+\mathrm{x}} \mathrm{Co}_{5-}$ ${ }_{\mathrm{y}} \mathrm{Cu}_{\mathrm{y}} \mathrm{O}_{15+\delta} \quad$ solid solution. $\quad$ a: $\quad \mathrm{Sr}_{6.00} \mathrm{Co}_{4.75} \mathrm{Cu}_{0.25} \mathrm{O}_{15+\delta}, \quad$ b: $\quad \mathrm{Sr}_{6.12} \mathrm{Co}_{4.75} \mathrm{Cu}_{0.25} \mathrm{O}_{15+\delta}, \quad$ c: $\mathrm{Sr}_{6.25} \mathrm{Co}_{4.69} \mathrm{Cu}_{0.31} \mathrm{O}_{15+\delta}, \quad$ d: $\quad \mathrm{Sr}_{6.00} \mathrm{Co}_{4.50} \mathrm{Cu}_{0.50} \mathrm{O}_{15+\delta}, \quad$ e: $\quad \mathrm{Sr}_{6.12} \mathrm{Co}_{4.50} \mathrm{Cu}_{0.50} \mathrm{O}_{15+\delta}, \quad$ f: $\mathrm{Sr}_{6.25} \mathrm{Co}_{4.38} \mathrm{Cu}_{0.62} \mathrm{O}_{15+\delta}, \mathrm{g}: \mathrm{Sr}_{6.00} \mathrm{Co}_{4.25} \mathrm{Cu}_{0.75} \mathrm{O}_{15+\delta}, \mathrm{h}: \mathrm{Sr}_{6.25} \mathrm{Co}_{4.06} \mathrm{Cu}_{0.94} \mathrm{O}_{15+\delta}$.

\section{Table captions}

Table 1: Phases observed in selected samples after equilibration and crystallographic data for the majority phases. 


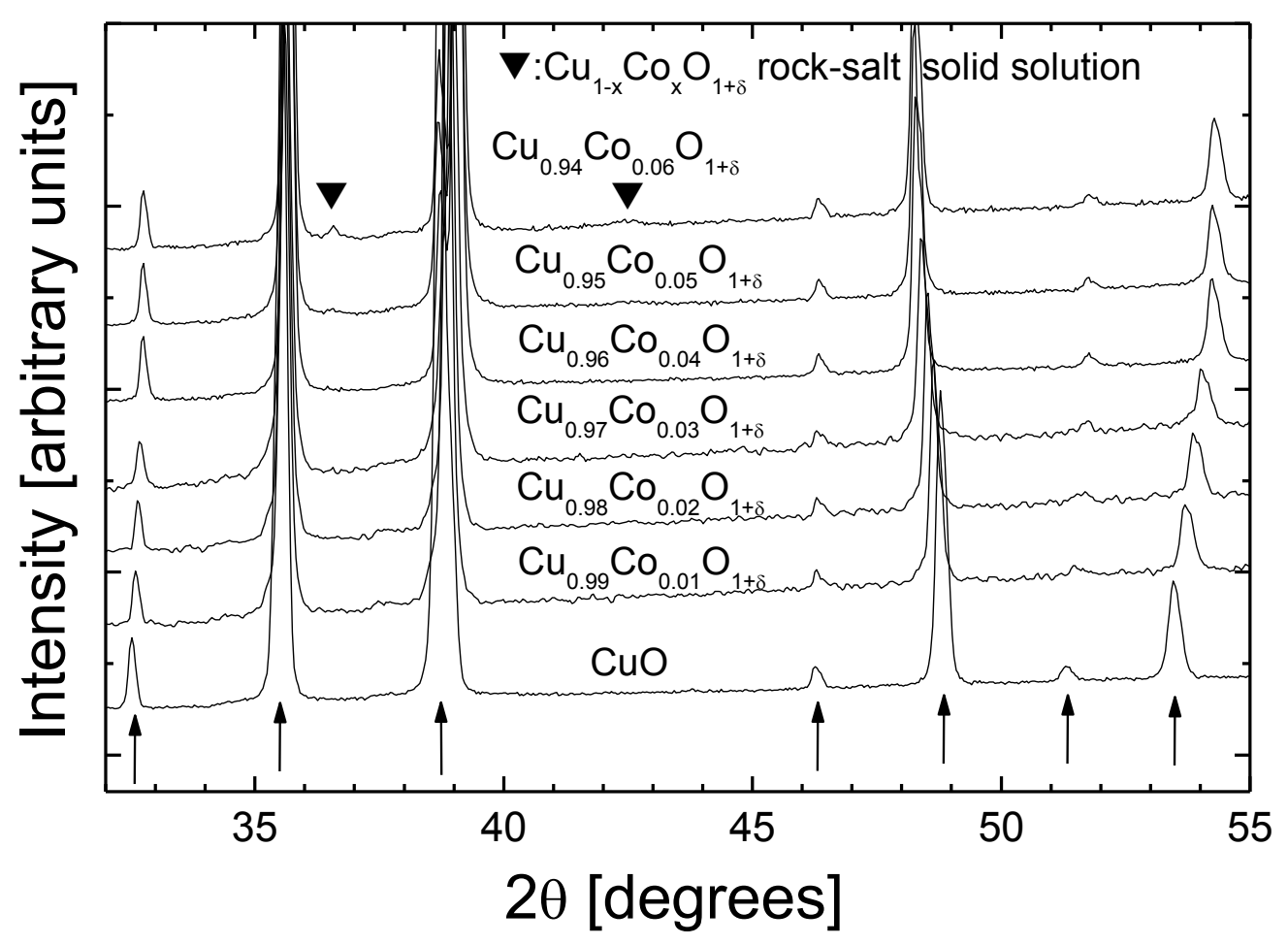




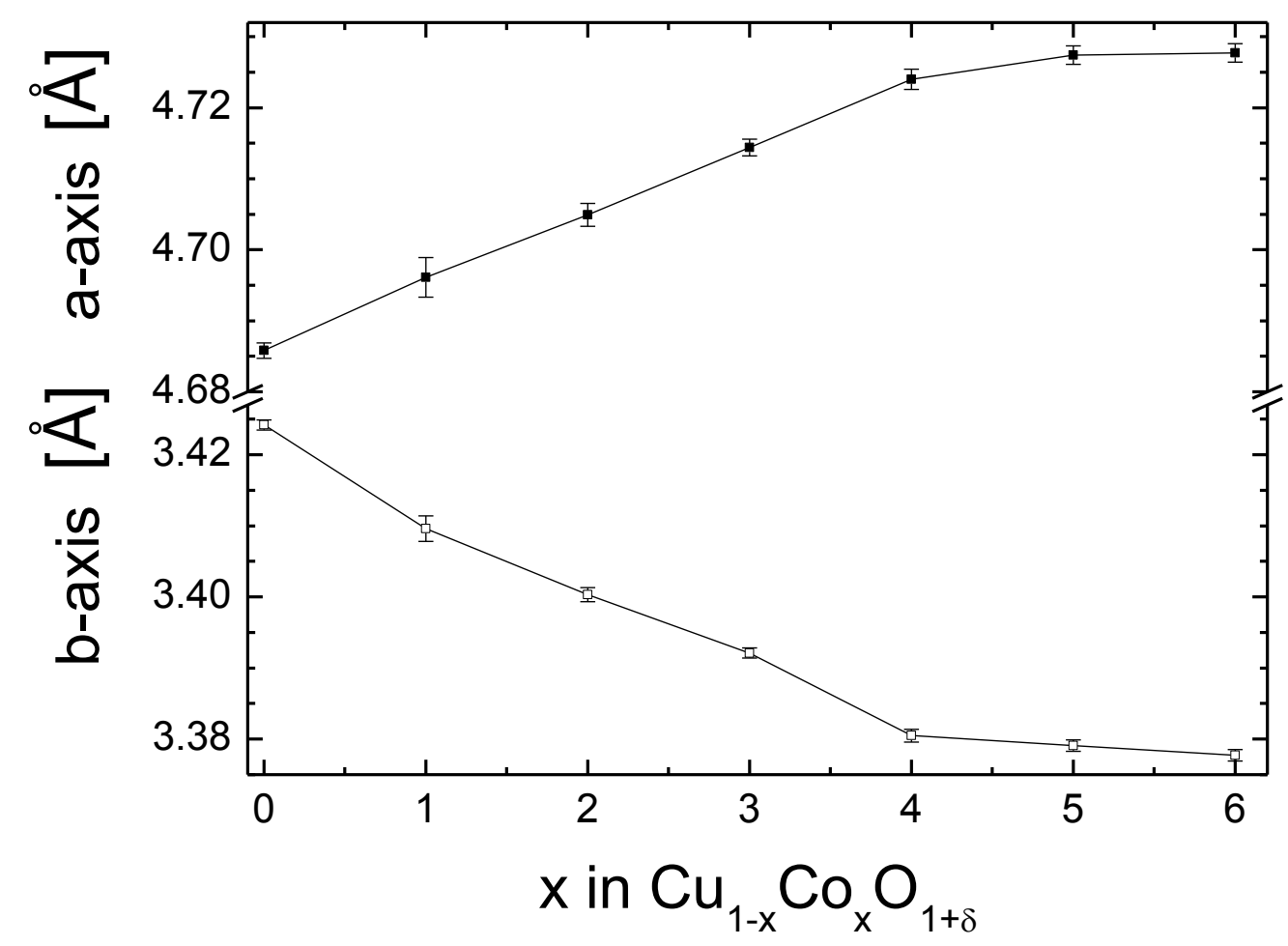

504 


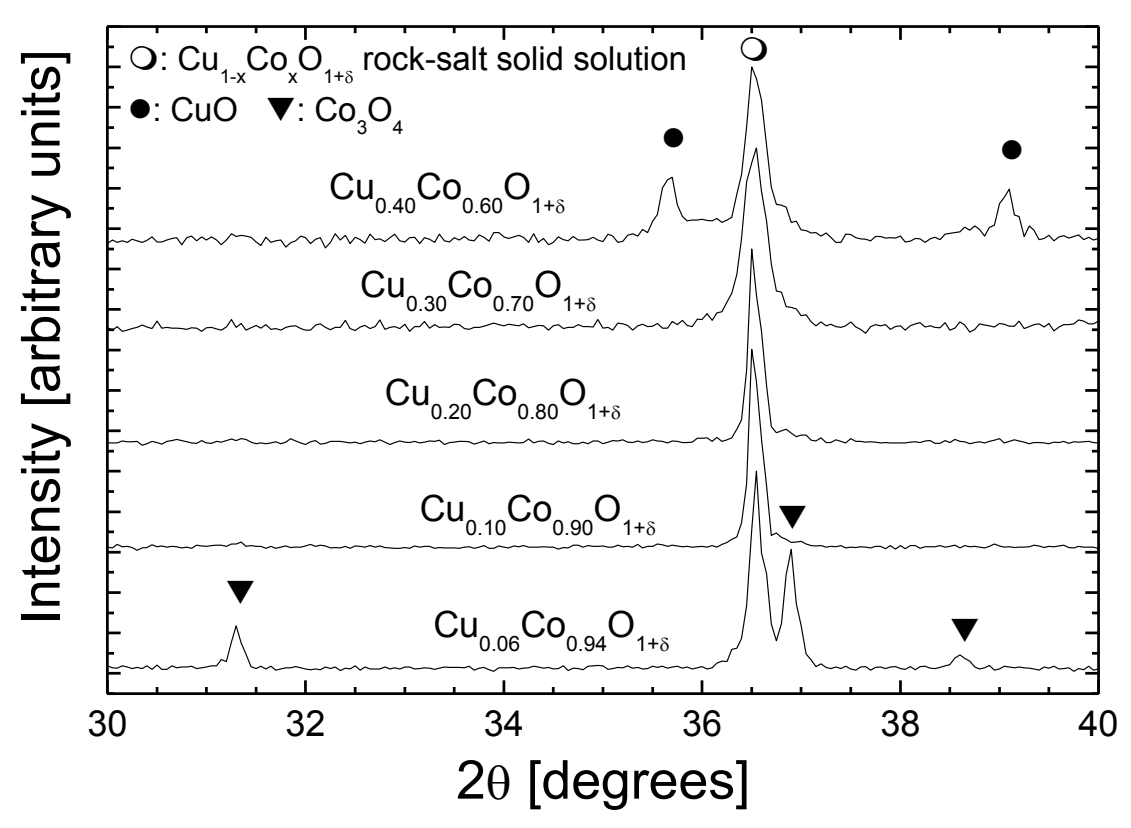




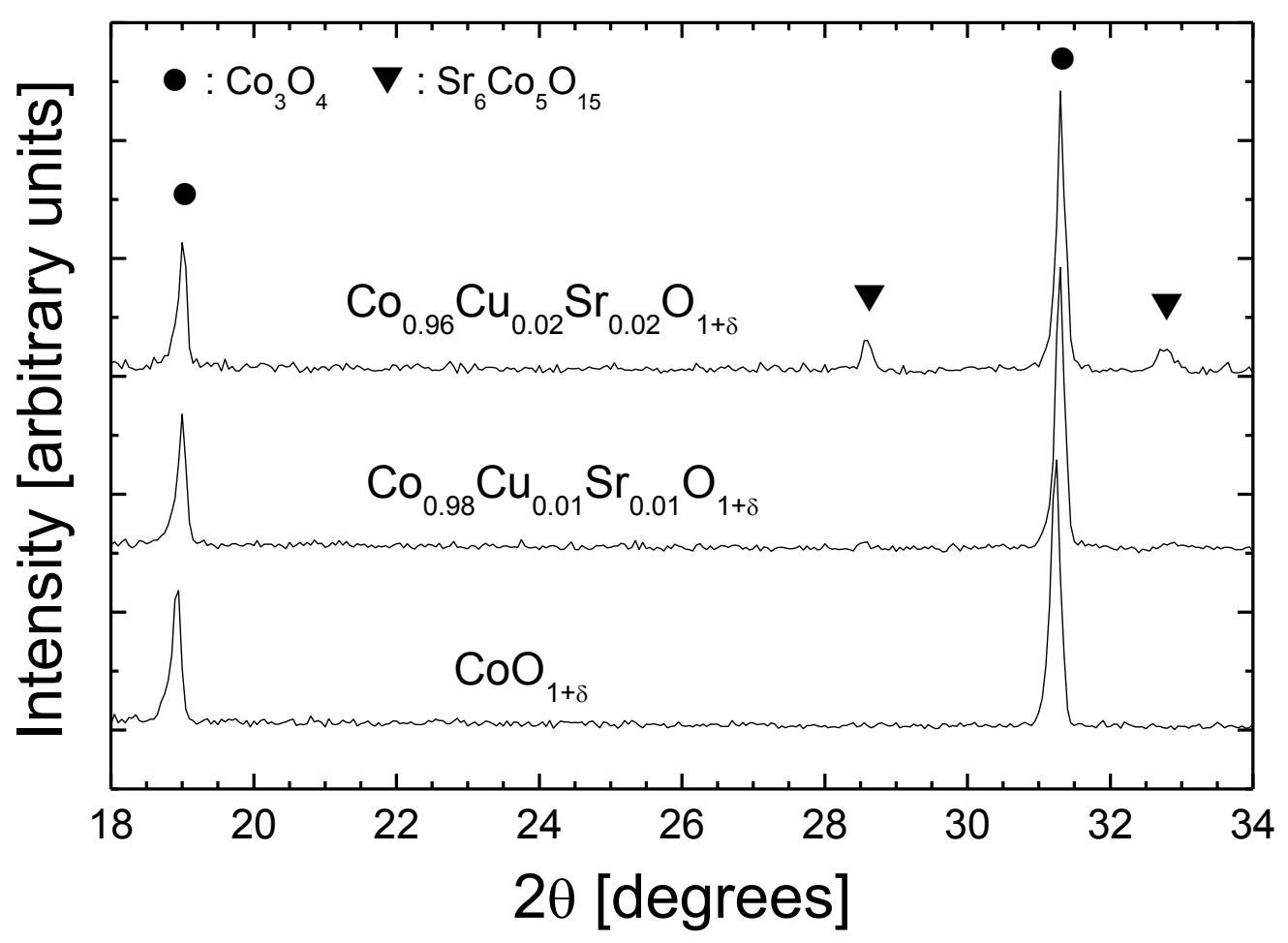




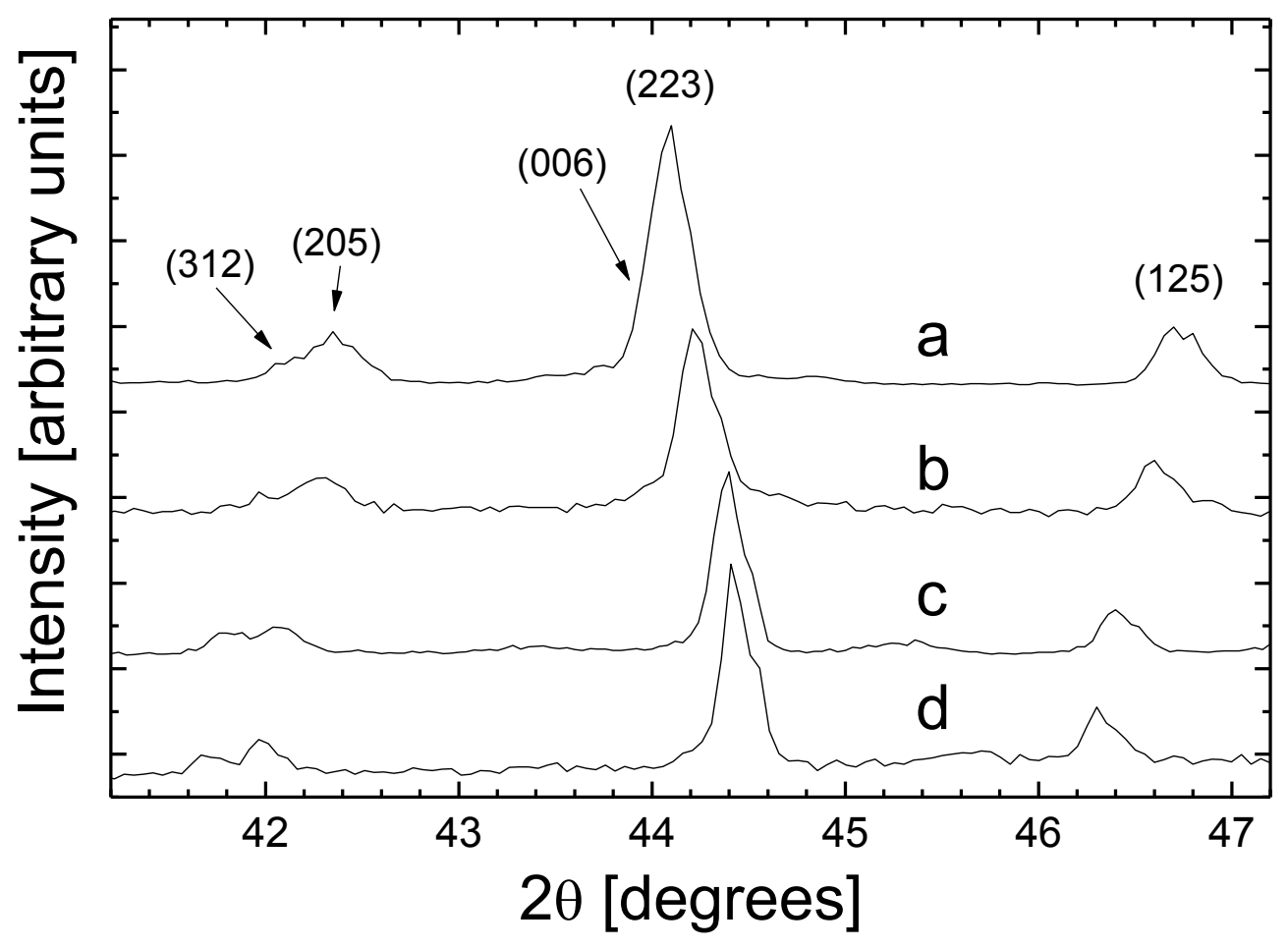




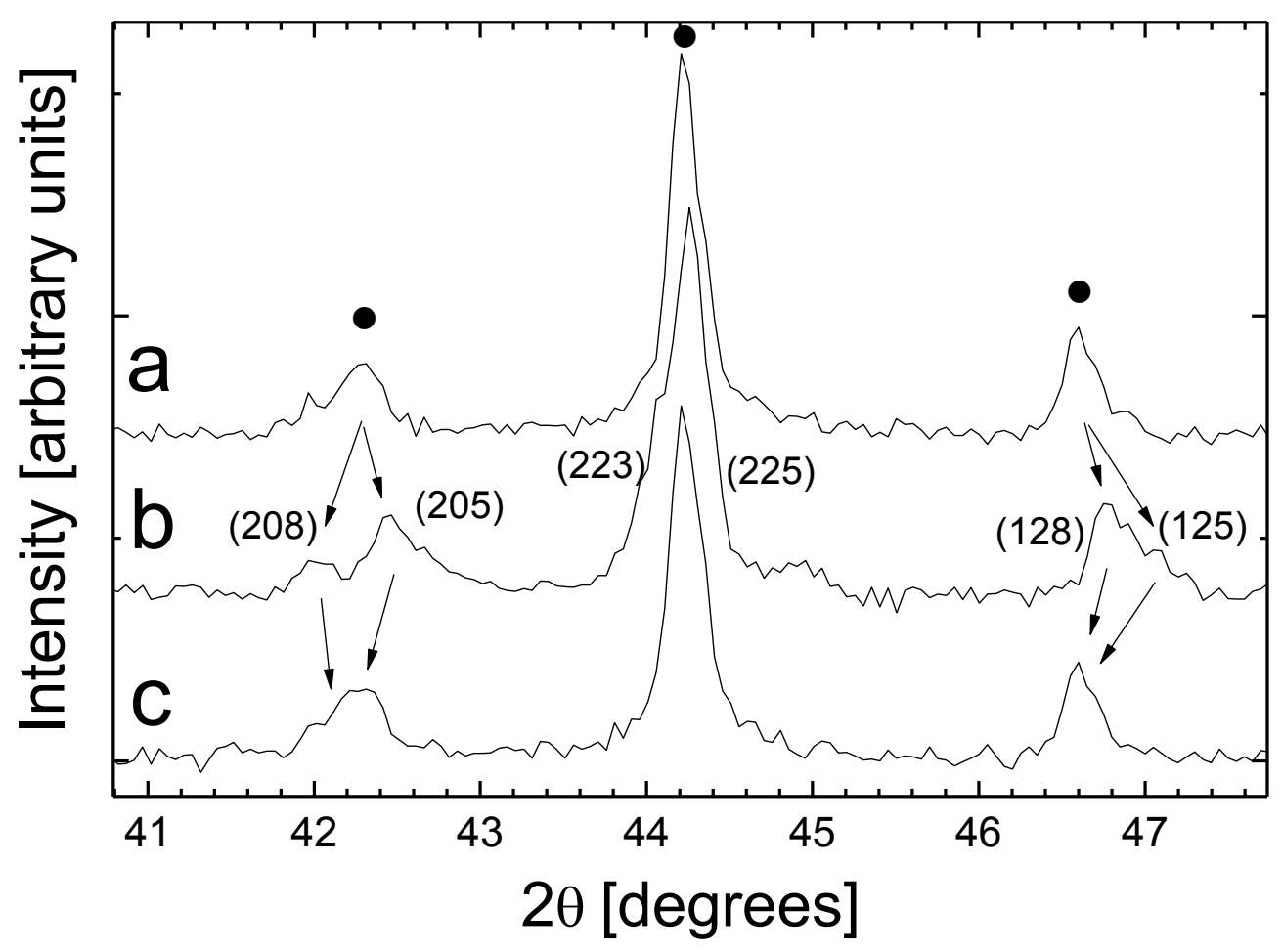




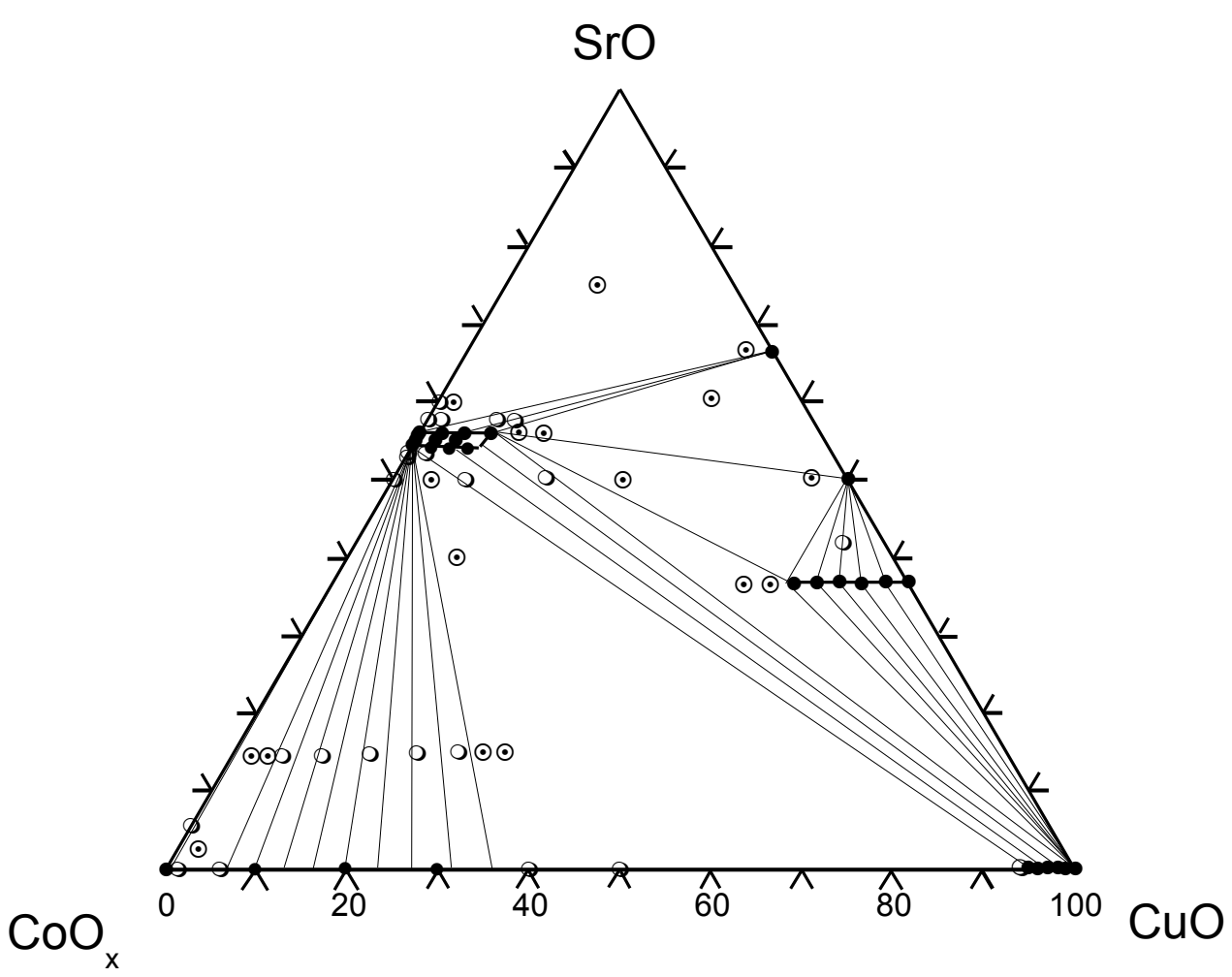

578

579

580

Figure 7

581

582

583

584

585

586

587

588 


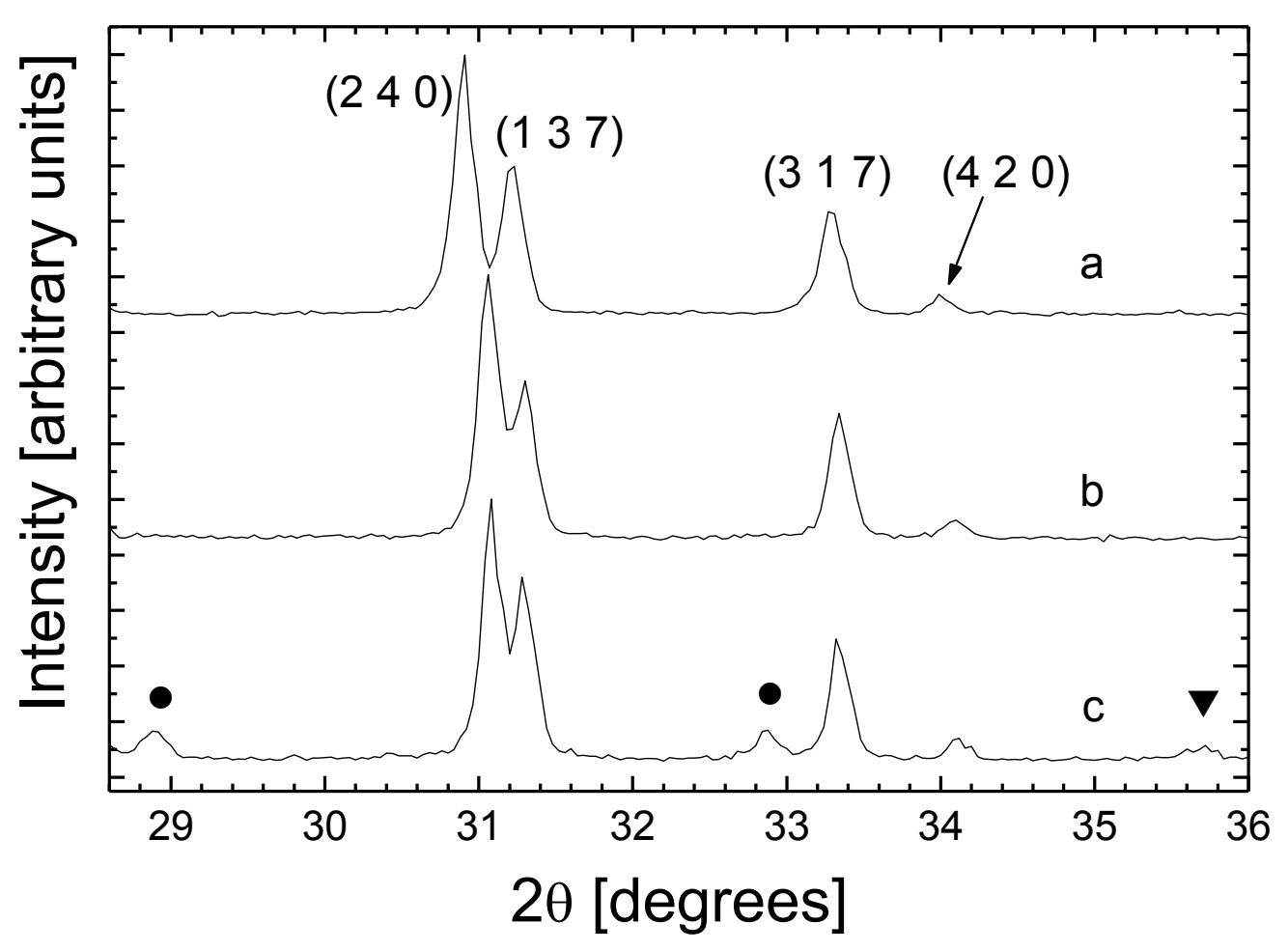




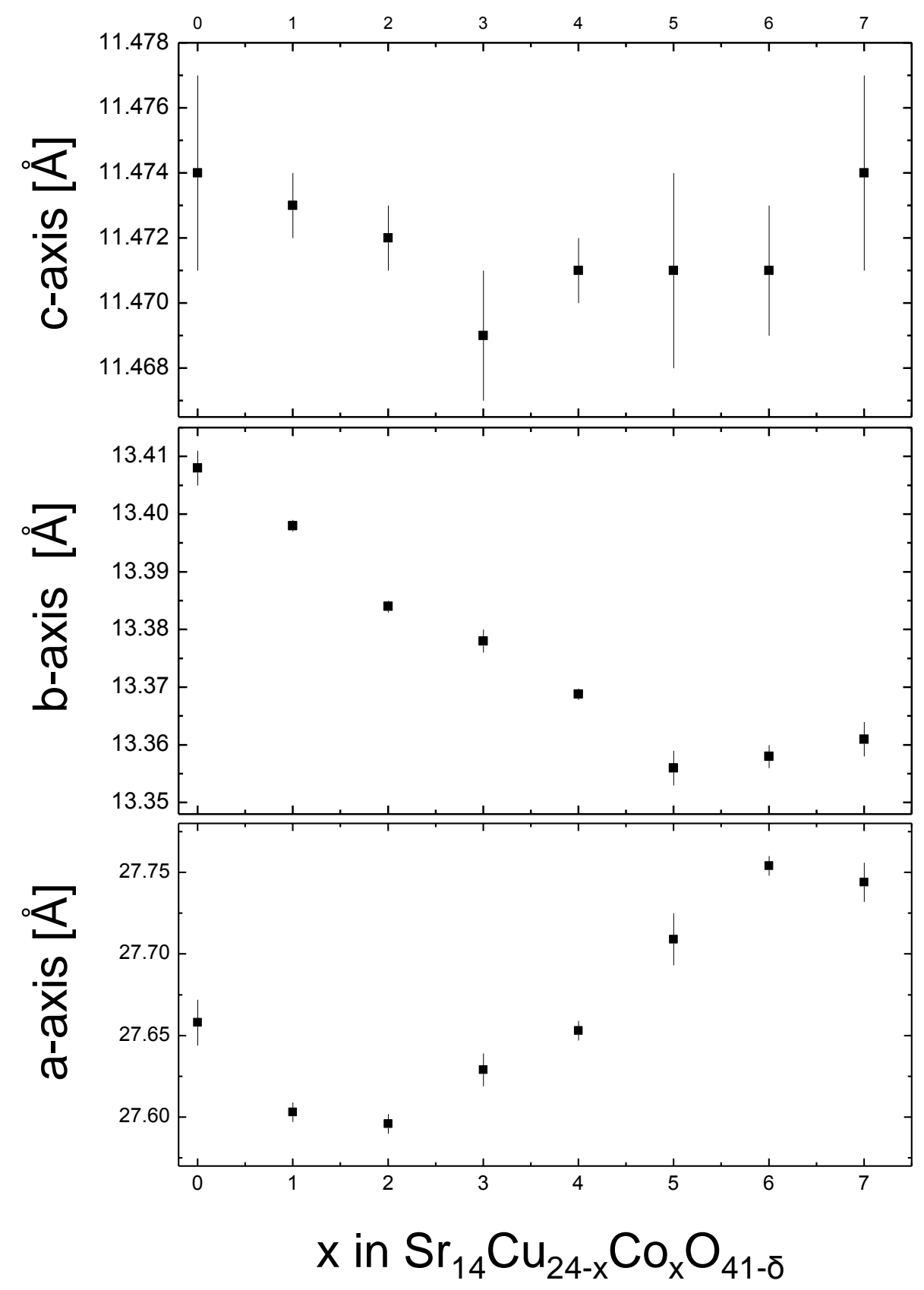



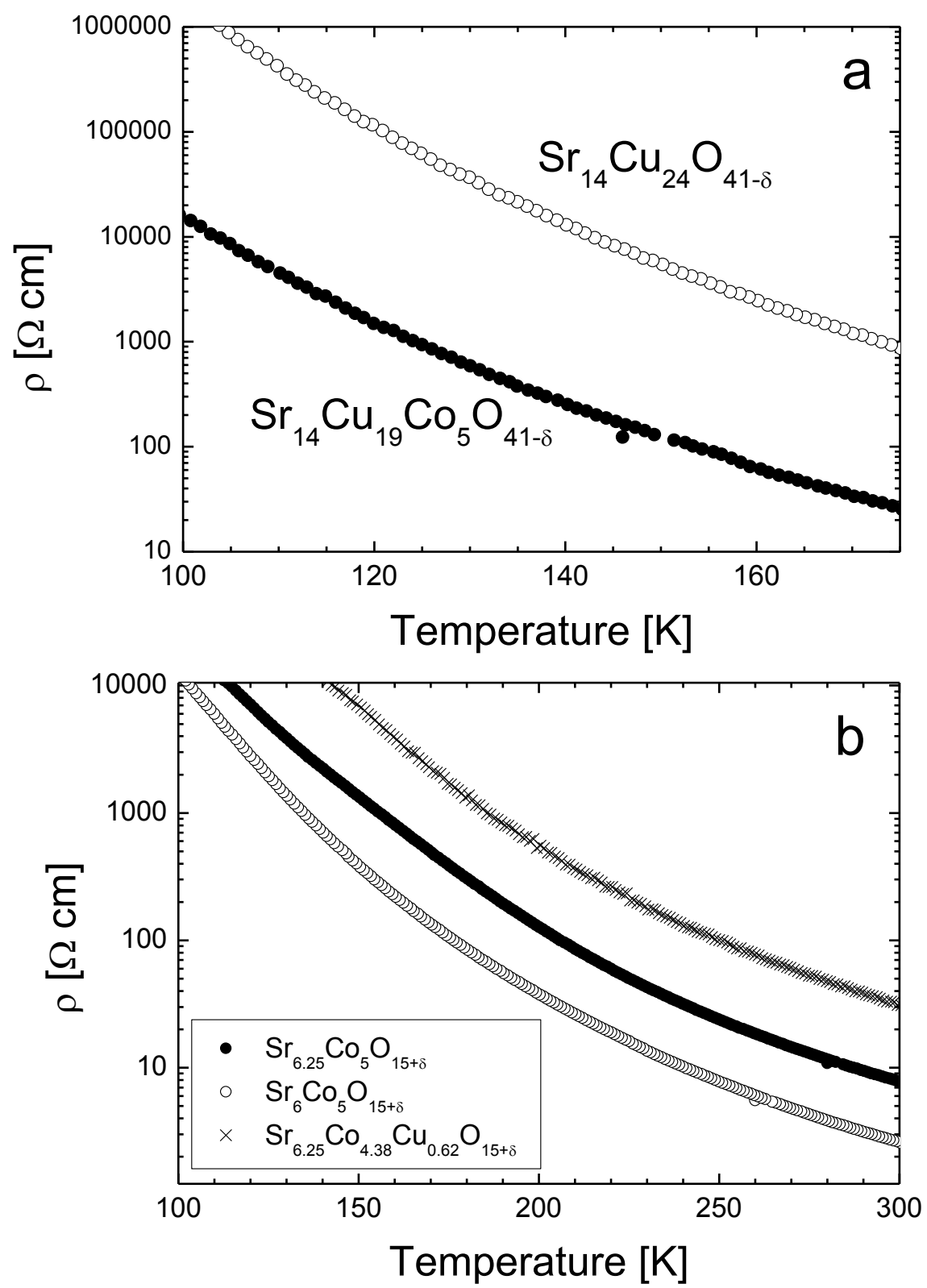

604 


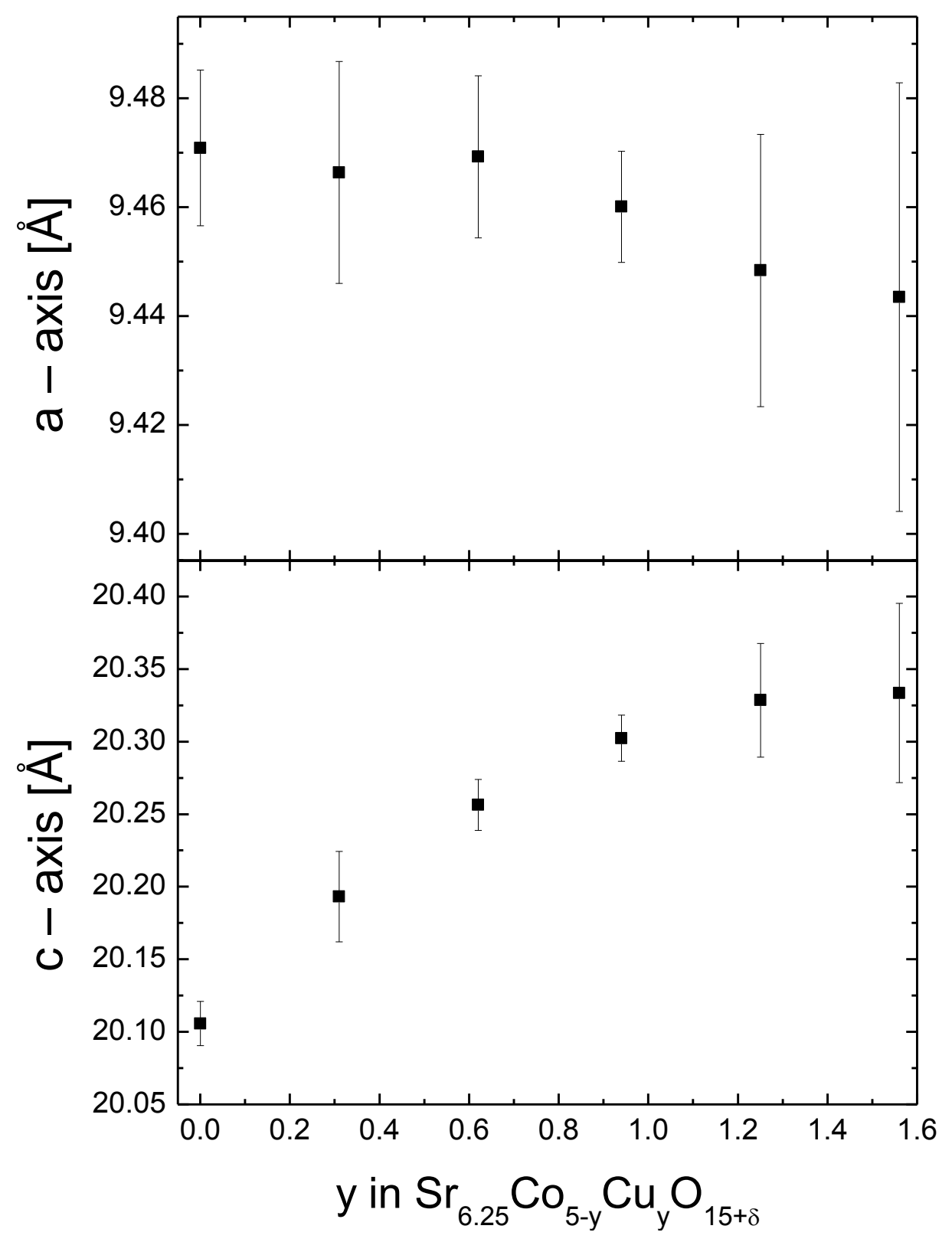

614

615 


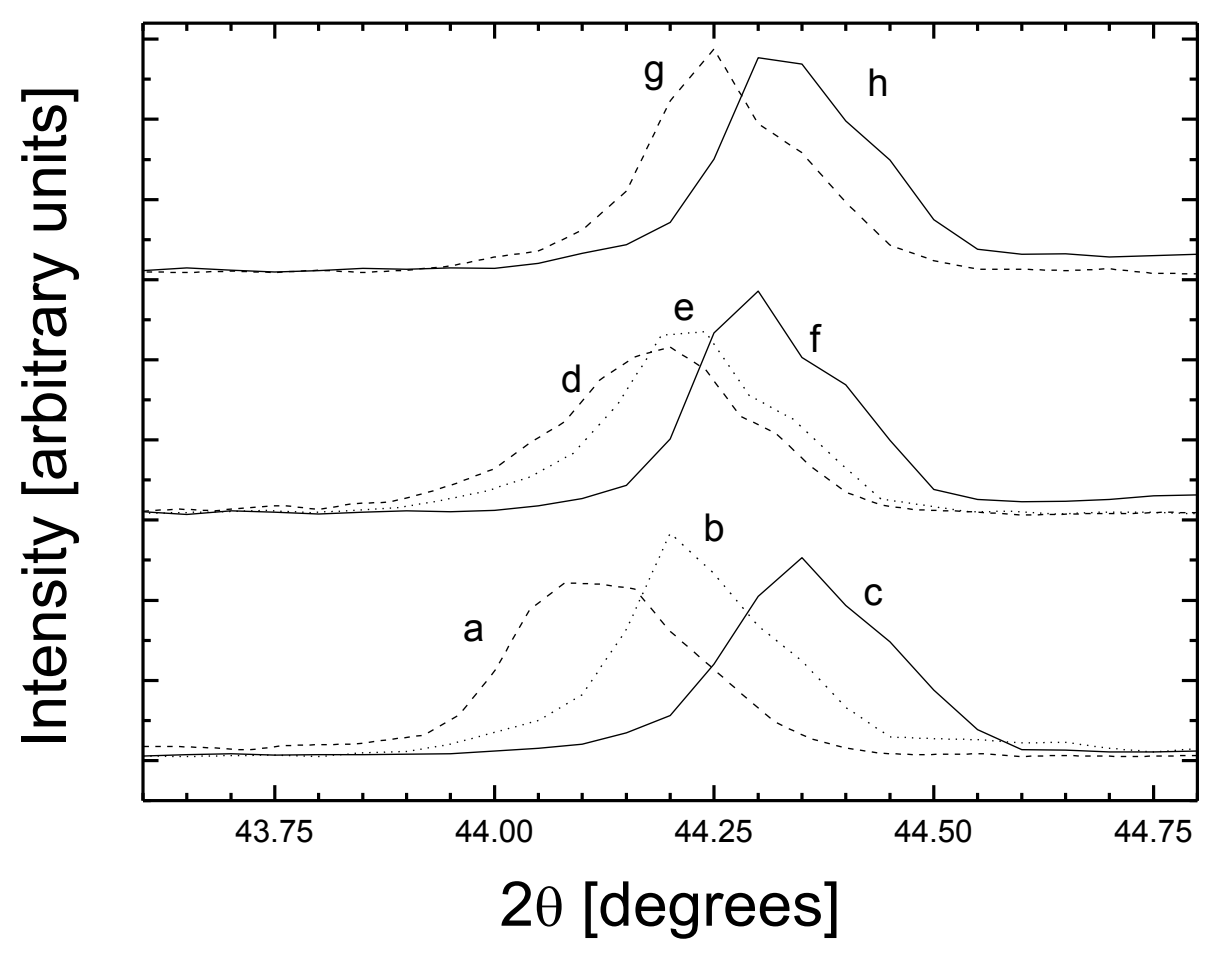

623

624

625

Figure 12

626

627 


\begin{tabular}{|c|c|c|c|c|c|c|}
\hline $\begin{array}{l}\text { Nominal cation ratio } \\
\qquad \mathrm{Co}: \mathrm{Sr}: \mathrm{Cu} \\
\end{array}$ & Phases $(\mathrm{XRD}) *$ & Space group $* *$ & $\mathbf{a}[\AA]$ & $\begin{array}{c}\text { ttice para } \\
\text { b [̊̊] }\end{array}$ & 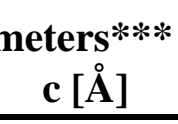 & $\beta\left[^{\circ}\right]$ \\
\hline $\begin{array}{ll}0: & 0: 100 \\
1: & 0: 99 \\
2: & 0: 98 \\
3: & 0: 97 \\
4: & 0: 96 \\
5: & 0: 95 \\
6: & 0: 94\end{array}$ & $\begin{array}{l}\mathrm{CuO} \\
\mathrm{CuO} \\
\mathrm{CuO} \\
\mathrm{CuO} \\
\mathrm{CuO} \\
\mathrm{CuO}\left(\mathrm{Cu}_{1-\mathrm{x}} \mathrm{Co}_{\mathrm{x}} \mathrm{O}_{1+\delta} \text { rock-salt ss }\right) \\
\mathrm{CuO}\left(\mathrm{Cu}_{1-\mathrm{x}} \mathrm{Co}_{\mathrm{x}} \mathrm{O}_{1+\delta} \text { rock-salt ss }\right)\end{array}$ & $\begin{array}{l}\mathrm{C} 2 / \mathrm{c} \\
\mathrm{C} 2 / \mathrm{c} \\
\mathrm{C} 2 / \mathrm{c} \\
\mathrm{C} 2 / \mathrm{c} \\
\mathrm{C} 2 / \mathrm{c} \\
\mathrm{C} 2 / \mathrm{c} \\
\mathrm{C} 2 / \mathrm{c}\end{array}$ & $\begin{array}{l}4.686(2) \\
4.696(3) \\
4.705(2) \\
4.714(2) \\
4.724(2) \\
4.727(2) \\
4.728(2)\end{array}$ & $\begin{array}{l}3.424(1) \\
3.410(2) \\
3.400(1) \\
3.392(1) \\
3.381(1) \\
3.379(1) \\
3.378(1)\end{array}$ & $\begin{array}{l}5.132(2) \\
5.129(4) \\
5.129(2) \\
5.129(2) \\
5.128(2) \\
5.128(2) \\
5.128(2)\end{array}$ & $\begin{array}{r}99.43(3) \\
99.68(6) \\
99.85(3) \\
100.02(3) \\
100.18(3) \\
100.11(3) \\
100.22(3)\end{array}$ \\
\hline 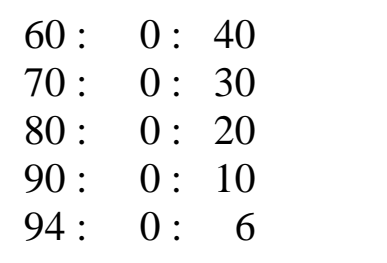 & $\begin{array}{l}\mathrm{Cu}_{1-\mathrm{x}} \mathrm{Co}_{\mathrm{x}} \mathrm{O}_{1+\delta} \text { rock-salt ss }(\mathrm{CuO}) \\
\mathrm{Cu}_{1-\mathrm{x}} \mathrm{Co}_{\mathrm{x}} \mathrm{O}_{1+\delta} \text { rock-salt ss } \\
\mathrm{Cu}_{1-\mathrm{x}} \mathrm{Co}_{\mathrm{x}} \mathrm{O}_{1+\delta} \text { rock-salt ss } \\
\mathrm{Cu}_{1-\mathrm{x}} \mathrm{Co}_{\mathrm{x}} \mathrm{O}_{1+\delta} \text { rock-salt ss } \\
\mathrm{Cu}_{1-\mathrm{x}} \mathrm{Co}_{\mathrm{x}} \mathrm{O}_{1+\delta} \text { rock-salt ss }\left(\mathrm{Co}_{3} \mathrm{O}_{4}\right)\end{array}$ & $\begin{array}{l}\mathrm{Fd}-3 \mathrm{~m} \\
\mathrm{Fd}-3 \mathrm{~m} \\
\mathrm{Fd}-3 \mathrm{~m} \\
\mathrm{Fd}-3 \mathrm{~m} \\
\mathrm{Fd}-3 \mathrm{~m}\end{array}$ & $\begin{array}{l}4.258(2) \\
4.257(1) \\
4.257(2) \\
4.256(2) \\
4.254(2)\end{array}$ & $\begin{array}{l}------ \\
------ \\
------ \\
------ \\
------\end{array}$ & $\begin{array}{l}------ \\
------ \\
------ \\
------\end{array}$ & $\begin{array}{l}------ \\
------ \\
------ \\
------\end{array}$ \\
\hline $\begin{array}{rll}100: & 0: & 0 \\
99: & 0: & 1\end{array}$ & $\begin{array}{l}\mathrm{Co}_{3} \mathrm{O}_{4} \\
\mathrm{Co}_{3} \mathrm{O}_{4}\left(\mathrm{Cu}_{1-\mathrm{x}} \mathrm{Co}_{\mathrm{x}} \mathrm{O}_{1+\delta} \text { rock-salt ss }\right)\end{array}$ & $\begin{array}{l}\text { Fm-3m } \\
\text { Fm-3m }\end{array}$ & $\begin{array}{l}8.0848(9) \\
8.0826(9)\end{array}$ & ----- & ----- & ----- \\
\hline
\end{tabular}

\section{Table 1}




\section{Table 1 (Cont.)}

\begin{abstract}
$0.0: 14.0: 24.0$
$1.0: 14.0: 23.0$

$2.0: 14.0: 22.0$

$3.0: 14.0: 21.0$

$4.0: 14.0: 20.0$

$5.0: 14.0: 19.0$

$6.0: 14.0: 18.0$
\end{abstract}

\author{
$\mathrm{Cccm}$ \\ $\mathrm{Cccm}$ \\ $\mathrm{Cccm}$ \\ $\mathrm{Cccm}$ \\ $\mathrm{Cccm}$ \\ $\mathrm{Cccm}$
}

$\mathrm{Sr}_{14} \mathrm{Cu}_{24} \mathrm{O}_{41}$

$\mathrm{Sr}_{14} \mathrm{Cu}_{24} \mathrm{O}_{41} \quad\left(\mathrm{CuO}, \mathrm{Sr}_{6+\mathrm{x}} \mathrm{Co}_{-\mathrm{y}} \mathrm{Cu}_{\mathrm{y}} \mathrm{O}_{15+\delta}\right)$ $\begin{array}{llll}11.474(3) & 13.408(3) & 27.658(7) & ---- \\ 11.473(1) & 13.398(1) & 27.603(3) & ---- \\ 11.472(1) & 13.384(1) & 27.596(2) & ---- \\ 11.469(2) & 13.378(2) & 27.629(5) & ---- \\ 11.471(1) & 13.369(1) & 27.653(3) & ---- \\ 11.471(3) & 13.356(3) & 27.709(8) & ---- \\ 11.453(2) & 13.358(2) & 27.754(3) & ----\end{array}$
$5.00: 6.25: 0.00$

$4.69: 6.25: 0.31$

$4.38: 6.25: 0.62$

$4.06: 6.25: 0.94$

$3.75: 6.25: 1.25$

$3.44: 6.25: 1.56$

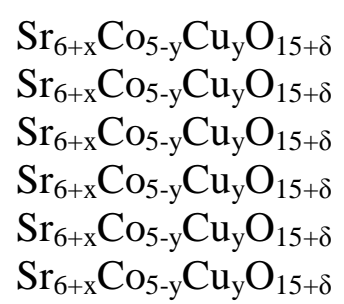

$\mathrm{P} 3 \mathrm{c} 1$

$\mathrm{P} 3 \mathrm{c} 1$

$\mathrm{P} 3 \mathrm{c} 1$

$\mathrm{P} 3 \mathrm{c} 1$

$\mathrm{P} 3 \mathrm{c} 1$

$\left(\mathrm{Sr}_{2} \mathrm{CuO}_{3}, \mathrm{SrCuO}_{2}\right) \quad \mathrm{P} 3 \mathrm{c} 1$

$\begin{array}{llll}9.471(14) & ----- & 20.106(15) & ----- \\ 9.466(20) & ---- & 20.193(31) & ---- \\ 9.469(15) & ----- & 20.257(17) & ---- \\ 9.460(11) & ---- & 20.302(16) & ---- \\ 8.448(25) & ---- & 20.329(39) & ---- \\ 8.444(39) & ----- & 20.337(62) & ----\end{array}$

* Phases between brackets are minority phases

** Space group of the majority phase

*** The lattice parameters are those of the majority phase

Table 1 (end) 
J. Phase Equilib. Diffus. (2017). https://doi-org.proxy.findit.dtu.dk/10.1007/s11669-017-0581-4 